\title{
Understanding the role of epigenomic, genomic and genetic alterations in the development of endometriosis (Review)
}

\author{
HIROSHI KOBAYASHI, SHOGO IMANAKA, HARUKI NAKAMURA and AYUMI TSUJI \\ Department of Obstetrics and Gynecology, Nara Medical University, \\ Kashihara, Nara 634-8522, Japan
}

Received February 18, 2014; Accepted March 3, 2014

DOI: $10.3892 / \mathrm{mmr} .2014 .2057$

\begin{abstract}
Endometriosis is a complex disease influenced by genetic, epigenetic and environmental factors. The aim of the present study was to describe genomic instability, genetic polymorphisms and their haplotype, epigenetic alterations associated with predisposition to endometriosis, and the key factors associated with endometriosis-related ovarian neoplasms. Focus has been given on the developing paradigm that epigenetic alterations or genetic mutations in endometriosis may start in utero or in adolescent and young adults. A search was conducted between 1966 and 2010 through the English language literature (online Medline PubMed database) using the keywords endometriosis combined with epigenetic, genetic and environment. Genetic/epigenetic alterations include single-nucleotide polymorphisms (SNPs), copy number variation, loss of heterozygosity ( $\mathrm{LOH})$, and promoter methylation. Several genes with genetic polymorphisms analyzed in the present study tended to overlap previously reported endometriosis susceptibility genes. Retrograde menstruation leads to iron overload, which facilitates the accumulation of somatic mutations through Fenton reaction-mediated oxidative stress. The epigenetic disruption of gene expression plays an important role in the development of endometriosis through interaction with environmental changes. There seems to be at least three spatiotemporally distinct phases of the development of endometriosis: the initial phase of genetic background inherited from parents; followed by epigenetic modifications in the female offspring; and iron overload, which is subject to dynamic modulation later in life. In conclusion, the marked regulation of endometriosis susceptibility genes may stem from a mechanism responsible for epigenetic and genetic mutations based on the microenvironmental changes.
\end{abstract}

Correspondence to: Professor Hiroshi Kobayashi, Department of Obstetrics and Gynecology, Nara Medical University, 840 Shijo-cho, Kashihara, Nara 634-8522, Japan

E-mail: hirokoba@naramed-u.ac.jp

Key words: endometriosis, epigenetic, genetic, environment

\section{Contents}

1. Introduction

2. Literature search

3. Microenvironment

4. Genetic instability

5. Single-nucleotide polymorphism (SNP) haplotype analysis

6. Somatic mutations and alterations in endometriosis-related carcinogenesis

7. Mitochondrial DNA (mtDNA) mutations

8. Epigenetic alterations

9. Epidemiology

10. Discussion

\section{Introduction}

Endometriosis is a common gynecologic disease with an estimated frequency of $5-10 \%$ among the female population of reproductive age. This disorder is characterized by inflammation, but the pathogenesis of the disease remains unclear. A stepwise process of accumulation of genetic mutations or epigenetic alterations may contribute to the development of endometriosis under the influence of environmental factors such as inflammatory responses (1). Endometriosis is reported to be associated with the frequent up- and downregulation of disease susceptibility genes in several pathways including cytokines, inflammation, immune, oxidative stress, detoxification, hormone receptors, metabolism, matrix remodeling, adhesion molecules, growth factors, cell cycle regulation, signaling, oncogenes, and transcriptional regulation (2). The marked regulation of disease may be associated with genetic alterations (1). The common mechanisms leading to loss- or gain-of-function have a causal relationship to genomic instability, including microsatellite instability (MSI), chromosomal instability (CIN), loss of heterozygosity (LOH), single-nucleotide polymorphism (SNP), gene mutations, and mitochondrial DNA (mtDNA) mutations $(3,4)$. In addition, evidence has emerged indicating that a specific gene has been shown to regulate its neighbor genes by epigenetic mechanisms (5). Insights have emerged from various lines of evidence, including that endometriosis may be an epigenetic disease (6). 
This review focused on the relationship between genomic instability, gene mutations and epigenetic alterations associated with increased risk of the development of endometriosis.

\section{Literature search}

A computerized literature search was performed to identify relevant studies reported in the English language. We searched MEDLINE electronic databases (http://www.ncbi. nlm.nih.gov/sites/entrez) published between January 1966 and December 2013, combining the keywords 'endometriosis', 'genetic', 'epigenetic', and 'environment'. Various combinations of the terms were used, depending on the database searched. Each gene was also linked to the NCBI Entrez Gene pages (http://www.ncbi.nlm.nih.gov/sites/entrez). In addition, references in each article were searched to identify potentially missed studies.

\section{Microenvironment}

Transtubal retrograde flow and hemolysis occurring during menstruation result in the accumulation of high levels of prooxidant factors, such as heme and iron, into the peritoneal cavity (7). Free heme catalyzes oxidative reactions, but impairs lipid bilayers of mitochondria. Mitochondria are a major source for reactive oxygen species (ROS) production. Heme also acts as a pro-inflammatory molecule, leading to cellular injury and DNA damage (2). Furthermore, iron overload initiates a Fenton chemical reaction, which causes oxidative stress and large-scale genomic alterations (2). Persistent oxidative stress induces destruction of the peritoneal mesothelium followed by the overexpression of inflammatory cytokines and adhesion molecules for ectopic endometrial cells, which may cause the development of endometriosis (7). Increased ROS generation, secondary to the influx of heme and iron during retrograde menstruation, have been found in endometriosis $(8,9)$. Oxidative signals from the microenvironment may be required for the development, maintenance and progression of endometriotic precursor lesions. Therefore, endometriosis has been considered to be associated with a chronic inflammatory state leading to pro-inflammatory cytokine excess by oxidative stress (10).

It is well known that the fine-tuning of alterations in oxidant and antioxidant pathways as well as endogenous redox regulators have been reported in the endometrium, serum, or peritoneal fluid (8). Antioxidant defense enzymes provide protection against oxidative DNA damage from carcinogenspecific mutations. It is likely that endometriosis is inherited in a polygenic manner (11). Therefore, inherited sequence variations in specific genes that encode inflammatory and antioxidant defense proteins may alter disease predisposition and thus individual susceptibility to endometriosis.

Endometriosis is a benign disease, however, it shares some features with malignancy, and has been associated with an increased risk of malignant tumors, including epithelial ovarian carcinomas (endometrioid adenocarcinoma and clear cell carcinoma), other Müllerian-type tumors (Müllerian-type mucinous borderline tumor and serous borderline tumor) and sarcomas such as adenosarcoma and endometrial stromal sarcoma in the female pelvic cavity (12-14). The precise cellular and molecularmechanisms leading to endometriosis-associated ovarian carcinogenesis recently became more evident (15-19). Excessive iron accumulation in the pelvic cavity or endometriotic cysts leads to increased oxidative stress and inflammation. Abundant iron-induced ROS is thought to be mutagenic, and chronic exposure of ectopic endometrium to this microenvironment facilitates the accumulation of somatic mutations, which can cause non-regulated mitotic division, growth and migration, similar to malignant mechanisms $(3,10,18)$. This microenvironment is a possible link between endometriosis and tumor development (3). Environment-gene interactions may persistently occur in endometriosis as well as in endometriosis-related carcinogenesis.

\section{Genetic instability}

General. Endometriosis is characterized by genetic instability, which may play a role in disease establishment, maintenance and progression $(3,4)$. Three phenotypes of genomic instability are generally recognized in cancer: the phenotypes associated with microsatellite instability (MSI), chromosomal instability (CIN) and loss of heterozygosity (LOH).

Microsatellite instability (MSI). Mutations in DNA mismatch repair (MMR) genes result in failure to repair errors that occur during spontaneous DNA replication and are identified as responsible for Lynch syndrome (also known as hereditary non-polyposis colorectal cancer). MSI is a common feature of cancer, but may be uncommon in endometriosis and atypical endometriosis bordering the cancerous region $(20,21)$. The expression of MMR proteins was very weak in endometriosis, but was increased in ovarian carcinoma accompanied by endometriosis and ovarian carcinoma stepwisely with significant differences (22). A higher frequency of MSI was found in endometrioid adenocarcinoma of the ovary (20). However, Ali-Fehmi et al showed that a high frequency of MSI was detected in endometriosis (83\%) and atypical endometriosis (75\%), indicating no significant differences in the MSI between endometriosis and ovarian carcinoma (23). Differences in study design, sample size and methodological issues have been suggested as an explanation for the contradictory data. It is likely that MMR abnormalities may be involved in the malignant transformation of endometriosis. However, there are no data that provide biological and clinical significance of MMR genes in endometriosis itself. Additional studies are needed to confirm the validity and reproducibility of MSI in endometriosis.

Chromosomal instability (CIN). Chromosomal instability (CIN), also known as unequal chromosome distribution during cell division, or DNA copy number alteration underlies the transformation of cells toward malignancy. This phenomenon is a characteristic feature of the majority of cancer cells. Findings of recent studies have shown that there are tissue-specific loss of DNA copy number on chromosomal arms $1 p, 22 q$ and $X$, while gain of somatic DNA copy number alterations was identified on $6 p, 17 q$ and $20 q$ in women with endometriosis, suggesting that chromosomal instability is important in the development of endometriosis $(24,25)$. However, not all investigators identified chromosomal aberrations (26). Therefore, expert consensus was not achieved on the importance of CIN in endometriosis. 
Loss of heterozygosity ( $\mathrm{LOH})$. Numerous studies have documented loss of heterozygosity $(\mathrm{LOH})$ in endometriosis $(3,23,27-33)$. $\mathrm{LOH}$ is relatively common in endometriosis. Even small endometriotic cysts harbor $\mathrm{LOH}$ on chromosomal arms 9p, 11q or $22 q$ (32). Findings of previous studies have demonstrated that LOH on chromosomal arms 6q (28), $7 p(31), 9 p(29,30,32), 10 q(23,27,28), 11 q(30,32), 13 q(29)$, $16 q(33)$ and $22 q(30,32)$, was frequently $(15-50 \%)$ found in endometriosis, while no $\mathrm{LOH}$ was observed in normal endometrium (30). Such LOH may be involved in the development and maintenance of endometriosis. In total 30-60\% of endometriotic lesions showed $\mathrm{LOH}$ at one or more sites $(23,27,30)$. LOH was frequently observed on chromosome $6 \mathrm{q}(60.0 \%)$ and $10 \mathrm{q}(40.0 \%)$ in atypical endometriosis (28).

A recent genome-wide study identified a locus at 7p15.2 as an endometriosis-specific LOH (31). The chromosome 7p15.2 contains the homeobox A (HOXA) cluster, an important gene for endometriosis (http://www.ncbi.nlm.nih.gov/gene/3206). Some genes on chromosome 7p15.2 also showed a promising association with malignancy, including leukemia, non-small cell lung cancer, prostate cancer, and pancreatic cancer (34). The gene cadherin 1 (CDH1) located on chromosome 16q22.1 encodes the cell-cell adhesion molecule, E-cadherin. Many genes of the $\mathrm{CDH}$ family, $\mathrm{CDH} 1,3,5,8,11$ and 16 exist on chromosome 16q22.1. E-cadherin is lost during the process of epithelial-mesenchymal transition, which plays a role in the metastatic process. Goumenou et al found that $\mathrm{LOH}$ on cyclin-dependent kinase inhibitor 2A [CDKN2A, also known as p16(Ink4), chromosomal location, 9p21], galactose-1-phosphate uridylyltransferase (GALT, 9p13), tumor protein p53 (TP53, 17p13.1) and apolipoprotein A-II (APOA2, 1q23.3), occurs in endometriosis (35). Mutations in the phosphatase and tensin homolog deleted on chromosome 10 (PTEN) gene are associated with endometriosis (36). The PTEN gene on chromosome $10 \mathrm{q} 23.3$ is also the most frequently deleted tumor suppressor gene in human cancers. In general, LOH on chromosome 10q23.3 was associated with more than half of solitary endometriotic cysts and approximately one third of ovarian carcinomas $(23,27)$.

Endometriosis has been shown to be associated with an increased risk of developing ovarian endometrioid and clear cell carcinoma. LOH was common in endometrioid adenocarcinoma $(43 \%)$ but not common in clear cell carcinoma $(27,28)$. Some LOH states are common to all of the endometriotic, transitional and ovarian carcinoma tissues (27). Other cases have revealed that $\mathrm{LOH}$ events are detected in cancer cells alone, but not in transitional and endometriotic tissues (29). No cases show LOH events in endometriosis alone (27). Thus, $\mathrm{LOH}$ may be a step in the development of endometriosis as well as endometriosis-associated ovarian cancer.

\section{Single-nucleotide polymorphism (SNP) haplotype analysis}

Endometriosis is considered a genetic disease. This disorder is aggregated in families and individuals with an affected twin, suggesting that some subjects may have a genetic predisposition to developing endometriosis (37). Genetic background inherited from parents may confer susceptibility to endometriosis. The SNP represents a variation in the DNA sequence when a single nucleotide differs in an individual. Genomewide SNP analysis data (37) have provided valuable insights into the genetic basis of complex traits to identify common and rare variants underlying complex diseases.

Specific SNP alterations of genes and their highly interconnected genes have been previously identified (Table I). Table I shows genetic polymorphisms and their haplotype in selected functional category lists. The genetic polymorphisms in each gene significantly appear to differ in relation to endometriosis risk. The biological categories include inflammation and immune response, oxidative stress and detoxification, hormone receptors and metabolism, matrix remodeling, adhesion molecules, growth factors, cell cycle regulation, signaling and oncogenes, transcriptional regulation, human leukocyte antigens and microRNA regulation (Tables I and II). Endometriosis undergoes a variety of molecular changes depending on the ability to survive, attach, grow, and invade. Many molecular events involved in endometriosis pathogenesis contribute to its development and maintenance. Genes in the category of inflammation showed that endometriosis is characterized by an imbalance between the oxidative and antioxidative arms of the inflammatory system, resulting in the over production of proinflammatory cytokines, oxidative stress and detoxification molecules $(7,8)$. Since the results of some genes have been inconsistent, genetic polymorphism data are considered to be limited and conflicting. A majority of association studies are based on very simple models including one SNP or haplotype and small sample sizes. Thus, the evidence of an association between genetic polymorphisms in a single gene and endometriosis risk may be weak.

\section{Somatic mutations and alterations in endometriosis- related carcinogenesis}

Epithelial ovarian carcinomas have been divided into at least five subgroups: high-grade serous, endometrioid, clear cell, mucinous, and low-grade serous (38). Endometriosis is associated with an increased risk of developing ovarian endometrioid and clear cell carcinoma (14). In this section, we mainly focus on genetic alterations of atypical endometriosis and endometriosis-associated ovarian carcinomas (EAOC). EAOC carcinogenesis generally follows a gradual and stepwise accumulation of genetic mutations under the influence of chronic inflammation and hyperestrogenism for clear cell carcinoma and endometrioid adenocarcinoma, respectively (13). We describe specific genetic/genomic alterations that are aberrantly expressed in solitary endometriosis, endometriosis distant from ovarian carcinomas, contiguous endometriosis associated with ovarian carcinomas, and ovarian carcinomas. Endometriosis susceptibility genes are defined as specific genes with a higher frequency of chromosomal aberrations, somatic gain- or loss-of-function mutations, or hypermethylation in solitary endometriosis than in normal endometrium. These genes are highly sensitive to microenvironmental changes, particularly to alterations in the inflammatory milieu, and in the induction of (epi)genomic changes in endometriosis precursor lesions, which may eventually lead to endometriosis. These genes may only be involved in the development and maintenance of endometriosis. Genes responsible for tumor promotion are dervied 
Table I. Genetic polymorphisms in the selected functional category lists ${ }^{\mathrm{a}}$.

Categories

Cytokines, inflammation, immune and oxidative stress

Detoxification

Hormone receptors and metabolism

Matrix remodeling

Growth factors

Cell cycle regulation, signaling and oncogenes

Adhesion molecules

Transcriptional regulation

Human leukocyte antigens

microRNA

Others
Genetic polymorphisms
COX-2 (114), FCRL3 (115-117), IFNG (118-120), IL1A (121), IL1R1 (122,123), IL2 (124), IL6 (125,126), IL10 (127-133), IL16 (134), IL18 (135), KIR3DS1 (136), NFKB1 (137,138), NOS3 (139), TNFA (125,140-144), TNFR2 (141), TNFSF13B (145), TGFB1 (146,147), TLR4 (148), XRCC1 (45) and XRCC4 (46) CYP1A1 (58,149), CYP1B1 (149), CYP2C19 (150), CYP17 (151-154), CYP19 (155-158), GSTM1 (56-60), GSTT1 (52), GSTP1 (159) and NAT2 $(59,62)$ AHRR (52,160), AR (161), CETP (25), DRD2 (162), ESR1 (130,153,163-170), ESR2 (165,171-174), HSD17B1 (165,175,176), FSHR (155,177), HSD17B3 (155), LHB (178), NRIP1 (179) and PGR (176,180-184)

LOXL4 (185), MMP-1 (96,186,187), MMP-2 (188-190), MMP-3 (186), MMP-7 (191), MMP-9 (186,190,192), MMP-12 (193), MMP-13 (193), PAI-1 $(194,195)$ and TIMP-2 $(189,196)$

BDNF (197), IGF-II (198), IGFBP3 (199), IRS2 (200), FGF2 (201), EGFR (202), VEGF (203-211) and VEGFR-2 (212)

CDKN1B (213), CDKN2BAS (214,215), PDCD6 (206), PTPN22 $(217,218)$, TP53 (122,219-224), WNT4 (214) and STAT6 (225)

CDH1 (226-228), FN1 (214), ICAM1 (126,158,229), MUC2 (230) and MUC4 (231) CHD5 (232), FOXP3 (115), HOXA10 (233) and PPARG2 (234,235)

HLA-D (236) and HLA-DR (237)

let-7 microRNA (238)

ACE (237,240), AHSG (241), C3 (185), DNMT3L (242), GALT (35,53),

MTHFR (243), PEMT (243), SLC22A23 (244) and WHSC1 (244)

${ }^{a}$ The candidate SNPs represented 10 major functional categories. References are indicated in parentheses. SNPs, single-nucleotide polymorphisms.

from genes with further aberrations required for promotion to a premalignant state in contiguous endometriosis associated with ovarian carcinomas than in endometriosis distant from ovarian carcinomas or solitary endometriosis. Genes responsible for the malignant transformation of endometriosis and cancer progression are involved in malignant transformation in ovarian carcinomas as compared to contiguous endometriosis associated with ovarian carcinomas. Tables III and IV show (epi)genetically relevant information of endometriosis susceptibility genes, genes responsible for tumor promotion and genes responsible for the malignant transformation of endometriosis and cancer progression.

Endometriosis susceptibility gene candidates. These genes are associated with the transition from normal endometrium to non-atypical endometriosis components. Endometriosis susceptibility genes include PTEN $(3,23,27,28,36)$, v-myc avian myelocytomatosis viral oncogene homolog (MYC) $(39,40)$, catenin (cadherin-associated protein), $\beta 1,88 \mathrm{kDa}$ (CTNNB1) (30,41-44), X-ray repair complementing defective repair in Chinese hamster cells (XRCC) (45-48), B-cell CLL/ lymphoma 2 (BCL2) (49-51), galactose-1-phosphate uridylyltransferase (GALT) $(35,52-55)$, glutathione S-transferase mu 1 (GSTM1) (56-61) and N-acetyltransferase 2 (NAT2) $(59,62)$. These genes are associated with important aspects of tumor biology, including the regulation of cell growth and proliferation, detoxification, DNA base excision repair, cell adhesion, metabolism, differentiation, anti-apoptosis, angiogenesis, tumor suppression, and tumorigenesis. However, oncogenic events, including promoter hypermethylation and genetic mutations, associated with endometrial and ovarian cancers are uncommon in solitary endometriosis (63).

Gene candidates responsible for tumor promotion. Previous studies (Table III) have shown EAOC and coexisting endometriosis exhibit common molecular genetic alterations that were widely detected in ovarian carcinoma tissue and contiguous endometriotic tissue associated with ovarian carcinomas. These are defined as genes responsible for tumor promotion, including genes responsible for the malignant transformation of endometriosis and those responsible for ovarian cancer progression. Genetic mutations detected in the carcinoma samples were almost detected in the corresponding contiguous endometriosis samples. In a few genes, however, genetic alteration events are found in ovarian carcinoma tissue alone, but not in contiguous atypical endometriosis.

These specific genes are responsible for carcinoma progression. However, it is unlikely that patients showed genetic alteration events in the endometriotic tissue only (27).

Gene candidates responsible for malignant transformation of endometriosis. These genes play a role in the transition from 
Table II. Genetic polymorphisms and their haplotype in endometriosis.

Name Description Genetic polymorphisms and their haplotypes

Cytokines, inflammation, immune and oxidative stress
COX-2
Cyclooxygenase-2

FCRL3 Fc receptor-like 3

IFNG

Interferon- $\gamma$

$\begin{array}{ll}\text { IL1A } & \begin{array}{l}\text { Interleukin } 1 \alpha \\ \text { Interleukin } 1 \text { receptor, } \\ \text { type I }\end{array} \\ \text { IL-2R } & \text { Interleukin-2 receptor } \\ \text { IL-6 } & \text { Interleukin-6 }\end{array}$

IL-10 Interleukin-10

IL-16 Interleukin-16

IL-18 Interleukin-18

KIR3DS1 Killer cell immunoglobulin-like, receptor three domains, long cytoplasmic tail, 1
A significant genetic association between the COX-2 gene -765G/C polymorphism and advanced-stage endometriosis was demonstrated in Korean women (114).

A possible FOXP3 and FCRL3 interaction leads to a cumulative effect on the development of endometriosis (115). Data from this study point to a possible association of the FCRL3 -169C/T polymorphisms with endometriosis, especially minimal/mild endometriosis, and the haplotype AGAT may be protective against the development of the disease in Brazilian women (116). The FCRL3 C-169T polymorphism may play an important role in the pathogenesis of endometriosis and/or infertility (117). FCRL3 may play a role in regulation of the immune system.

The IFNG gene CA-repeat polymorphism is associated with susceptibility to endometriosis in South Indian women (120). The CA repeat polymorphism in the IFN- $\gamma$ gene may be associated with a risk of endometriosis in the South Korean population (199).

Candidate SNPs are located in and around the IL1A gene (121).

The IL1R1 1498T/C polymorphism is associated with early-stage endometriosis in Korean women (245). Polymorphisms at a $\mathrm{C} / \mathrm{A}$ transition at position 52 in exon $1 \mathrm{C}$ of the IL-1R1 gene showed protective risk for the development of endometriosis (123).

IL-2R $-627 * \mathrm{C}$ homozygote and $\mathrm{C}$ allele are related to higher susceptibility to endometriosis (124).

IL-6 -174C/G gene polymorphisms may be a risk factor for endometriosis for Asians (125).

IL-6 -634C/G and ICAM-1 469K/E polymorphisms synergistically affect the susceptibility for endometriosis in the Japanese population (126).

The IL-10 ACC/ACC genotype, which is known to be a 'low-producer' of IL-10, is associated with endometriosis (128). The IL10 -592 A/C polymorphisms conferred susceptibility to endometriosis (127).

The functional promoter polymorphism at IL-10 may play a role in the development of endometriosis (129). The -592 or $-819 \mathrm{C}$ allele of IL-10 are associated with endometriosis (130). IL-10 gene promoter polymorphisms at -819 and -592 sites are associated with endometriosis risk (131). An association between endometriosis and IL-10 gene promoter polymorphism exists, and the IL-10 -627 A allele is related to a higher susceptibility to endometriosis (132).

IL-10 promoter polymorphisms were associated with the production of anti-CA II ab in patients with endometriosis (133).

The rs4778889 T/C polymorphism of the IL-16 gene may be associated with risk of endometriosis in the Chinese population, especially in patients with pain phenotype (134).

IL-18 -607*A homozygote and A allele were positively correlated with the risk of developing endometriosis or the stage of endometriosis (135).

Polymorphism in KIRs may be associated with susceptibility for endometriosis (136). 
Table II. Continued.

Name Description Genetic polymorphisms and their haplotypes

NFKB1

NOS3

Nitric oxide synthase 3

TNFA

TNFR2

TNFSF13B

and BLyS

TLR4

$\mathrm{XRCC} 1$

$\mathrm{XRCC} 4$

Detoxification

CYP1A1 m1
Nuclear factor of $\kappa$ light polypeptide gene enhancer in B-cells 1

Tumor nectosis factor- $\alpha$

Tumor necrosis factor receptor 2

B lymphocyte stimulator, is also known as TNFSF13B, tumor necrosis factor (ligand) superfamily, member $13 \mathrm{~b}$

Transforming growth factor- $\beta 1$

Toll-like receptor 4

$\mathrm{X}$-ray repair complementing defective repair in Chinese hamster cells 1

X-ray repair complementing defective repair in Chinese hamster cells 4

Cytochrome P450, family 1, subfamily A, polypeptide 1
The -94 insertion/deletion ATTG polymorphism in the NFKB1 gene was positively associated both with moderate/severe endometriosis and idiopathic infertility (137). NFKB is a transcription regulator that is activated by various intracellular and extracellular stimuli such as cytokines, oxidant-free radicals, ultraviolet irradiation, and bacterial or viral products.

The T allele, encoding aspartic acid, of the Glu298Asp polymorphism of the NOS3 may be associated with advanced stage endometriosis in the Korean population (139). Nitric oxide, a reactive-free radical, is synthesized from L-arginine by NOS3, nitric oxide synthase 3 (endothelial cell).

The genotype frequencies at the TNFA:g.[-1031T/C] and the TNFA:g.[-863C/A] sites may be associated with advanced stage endometriosis in the Korean population (142).

TNF- $\alpha-238 \mathrm{~A} / \mathrm{G}$ gene polymorphisms may be a risk factor for endometriosis for Asians (125). TNFA promoter polymorphism was associated with susceptibility to endometriosis (144). The variability of the $-1031 \mathrm{~T} / \mathrm{C}$ polymorphism of the TNF- $\alpha$ gene may be associated with susceptibility to endometriosis (143). The -C850T TNFA gene polymorphism may be used as a relevant molecular marker to identify women with risk of developing endometriosis in Asian Indian women (140).

The haplotype alleles of the TNF- $\alpha$ and TNFR2 gene polymorphisms are genetic factors associated with endometriosis (141).

The results point to a possible association between BLyS $-817 \mathrm{C} / \mathrm{T}$ polymorphism and idiopathic infertility in a Brazilian population (145). BLyS is a cytokine that belongs to the TNF ligand family and plays an important role in the proliferation and differentiation of B cells.

The TC haplotype allele of TGFB1-509C/T and $868 \mathrm{~T} / \mathrm{C}$ polymorphisms may be associated with early-stage endometriosis in Korean women (146). T homozygote and T allele for TGFB1 are associated with higher susceptibility to endometriosis (191).

TLR4 896A/G polymorphism (rs4986790) is a functional polymorphism resulting in hypo-responsiveness of the receptor, thus resulting in peritoneal inflammation and the initiation of endometriosis (148).

XRCC1 Arg399Gln polymorphism is associated with higher susceptibility to endometriosis (45). The protein encoded by this gene is involved in the efficient repair of DNA single-strand breaks formed by exposure to ionizing radiation and alkylating agents.

XRCC4 codon $247 *$ A and XRCC4 promoter $-1394 *$ T related genotypes and alleles might be associated with endometriosis susceptibilities and pathogenesis (46).

The combination of CYP1A1 m1 polymorphism and GSTM1 null deletion is closely associated with penetration of the endometriosis phenotype (58). 
Table II. Continued.

Name Description Genetic polymorphisms and their haplotypes

CYP2C19 Cytochrome P450, family 2, subfamily C, polypeptide 19

CYP17-34 Cytochrome P450, family 17-34

CYP17 Cytochrome P450, family 17, subfamily A, polypeptide 1

CYP19 Cytochrome P450, family 19 (CYP19A1)

GSTM1 Glutathione

S-transferase mu 1

NAT2 N-acetyltransferase 2

(arylamine $\mathrm{N}$-acetyltransferase)

Hormone receptors and metabolism

$\begin{array}{ll}\text { AHRR } & \text { Aryl-hydrocarbon } \\ \text { receptor repressor }\end{array}$

AR

Androgen receptor

CETP

Cholesteryl ester transfer protein, plasma

DRD2

Dopamine receptor D2

ESR1 Estrogen receptor 1, also known as estrogen receptor- $\alpha$
CYP2C19*2 heterozygote genotype has a higher risk of developing endometriosis (150).

The CYP17-34 G variant, previously associated with increased $17 \beta$-estradiol production, contributed to stage I-II endometriosis in women from a Polish population (151).

A2A2 type mutation of the CYP17 gene was observed to be more frequent in patients with endometriosis (152).

The CYP17* T allele appears to be associated with a trend of increased risk of endometriosis (154).

Non-synonymous polymorphisms of CYP19A1 gene may modulate the risk of endometriosis in Taiwanese Chinese women $(155,156)$. AA and CC genotypes were significantly represented in Val 80 and $1558 \mathrm{G} / \mathrm{T}$ polymorphisms of CYP19 in patients affected with endometriosis (157). The $3 \mathrm{bp} \mathrm{I/D} \mathrm{polymorphism} \mathrm{of} \mathrm{the} \mathrm{CYP19}$ gene may be weakly associated with the susceptibility of endometriosis in a Japanese population (158).

An association was observed between endometriosis and the GSTM1 null deletion in South Indian women (56). The GSTM1* null genotype is associated with a higher risk of endometriosis development (57). The combination of CYP1A1 m1 polymorphism and GSTM1 null deletion is closely associated with penetration of the endometriosis phenotype (58). Involvement of NAT2 and GSTM1 detoxification system genes in the pathogenesis of endometriosis and the possible impact of NAT2 gene polymorphism in the development of different forms of this disease was noted (59). The unusually high frequency of homozygotes for the GSTM1 gene deletion among patients with endometriosis suggests a possible contribution of environmental toxins in the pathogenesis of this disease due to the absence or low activity of GSTM1 enzyme (60).

Altered NAT 2 enzyme activity may be a predisposition factor in endometriosis. Alternatively NAT 2 alleles may be in linkage disequilibrium with a susceptibility allele in the same chromosomal region (62). NAT2 is an enzyme that functions to activate and deactivate arylamine and hydrazine drugs and carcinogens.

The AHRR codon 185 and GSTT1 polymorphisms are associated with the risk of advanced stage endometriosis (52). AHRR codon 185 polymorphism was associated with susceptibility to and severity of endometriosis in Japanese women (160).

The 19 and 20 CAG repeats of the AR gene are associated with endometriosis (161).

The I405V polymorphism of the CETP gene plays an important role as an independent factor in the risk of endometriosis in women (25).

An excess of DRD2 polymorphism was found in exon 7 in women with peritoneal moderate/severe endometriosis (162).

The $\mathrm{X}$ allele of ER $\alpha-X b a \mathrm{I}$ is associated with endometriosis (130). The ER $\alpha(P v u I I$ and $X b a \mathrm{I})$ gene polymorphisms may be included among the genetic risk factors for endometriosis (167). Estrogen receptor- $\alpha$ thymine-adenine (TA) repeat polymorphisms may be a genetic risk factor for minimal or mild endometriosis (168).

ER $\alpha-351 \mathrm{XbaI}^{*} \mathrm{G}-$ and $-397 \mathrm{PvuII}{ }^{*} \mathrm{C}$-related genotypes/alleles were correlated with higher susceptibilities of endometriosis (166). 
Table II. Continued.

Name Description Genetic polymorphisms and their haplotypes

ESR1

ESR2

Estrogen receptor- $\beta$

FSHR

HSD17B1

HSD17B3

LH $\beta$

PGR

Matrix remodeling

LOXL4
Progesterone receptor

Lysyl oxidase-like 4

Follicle stimulating hormone receptor

Hydroxysteroid (17- $\beta)$ dehydrogenase 1

Hydroxysteroid (17- $\beta)$ dehydrogenase 3

Luteinizing hormone $\beta$

Matrix metalloproteinase
The ESR1 polymorphism rs3798573 A/G was associated with risk of endometriosis and infertile endometriosis in Han women from central China (164). ER $\alpha^{*} 14$ TA repeats and the CYP17* A1 allele are associated with an increased risk of endometriosis (153). The restriction enzyme $P v u \mathrm{II}$ polymorphism of the ER $\alpha$ gene is associated with the risk for endometriosis (169). The variability of the estrogen receptor gene likely contributes to the pathogenesis of endometriosis (170). Genetic variants in ESR 1 gene may modify susceptibility to endometriosis and influence the fertility status in endometriosis patients (165).

The AluI polymorphism in the ER $\beta$ gene is associated with an increased risk of stage IV endometriosis in a Japanese population (174). The frequency of the heterozygous A/G polymorphism of the ER- $\beta$ gene was 9 times higher in patients with endometriosis than in the control group (171). The ESR $2+1730 \mathrm{G} / \mathrm{A}$ polymorphism can be associated with risk of infertility and endometriosis-associated infertility (172). The ER $\beta$ gene $+1730 \mathrm{G} / \mathrm{A}$ polymorphism can be associated with the risk of the development of endometriosis, regardless of the stage of the disease (173). The proline allele is associated with substantial complaints (infertility associated with pain), when compared to the homozygous arginine genotype; we also found that the proline allele was more frequent in endometriosis patients (222).

Non-synonymous polymorphisms of the FSHR gene may modulate the risk of endometriosis in Taiwanese Chinese women $(155,156)$. Both the GG (680Ser/Ser) and GA (680Ser/Asn) genotypes of FSHR were associated with a significantly lower risk of endometriosis (177).

Genetic variants in the HSD17B1 gene may modify susceptibility to endometriosis and influence the fertility status in endometriosis patients (165). HSD17B1 polymorphisms are associated with an increased risk of endometriosis (176).

Non-synonymous polymorphisms of HSD17B3 gene may modulate the risk of endometriosis in Taiwanese Chinese women $(155,156)$.

The LH $\beta$ 1502G/A polymorphism may be involved in the predisposition to infertility and minimal/mild endometriosis-associated infertility (178).

PGR polymorphisms are associated with an increased risk of endometriosis (176). There is a significant correlation between PGR polymorphism and endometriosis (180). PGR heterozygosis genotype frequencies were shown to be statistically higher in endometriosis cases compared with controls (181). The presence of the PGR gene polymorphic allele $+331 \mathrm{~A}$ is associated with a reduced risk of deep infiltrating endometriosis compared with the healthy population controls (182).The PROGINS polymorphism of the PGR may be associated with an increased risk of endometriosis (183). PROGINS appears to be associated with endometriosis in Caucasian individuals (184).

Statistically significant differences in the allelic frequencies and genotype distribution of genetic variants in LOXL4 and C3 were documented in patients with endometriosis-associated infertility versus controls, and in patients with endometriosis versus controls, respectively in a Puerto Rican population (185).

Haplotypes of MMP-1, -3 , and -9 genes were related to a high risk for endometriosis (186). 
Table II. Continued.

\begin{tabular}{|c|c|c|}
\hline Name & Description & Genetic polymorphisms and their haplotypes \\
\hline MMP-1 & $\begin{array}{l}\text { Matrix } \\
\text { metalloproteinase-1 }\end{array}$ & $\begin{array}{l}\text { The MMP-1 promoter SNP may modify susceptibility to } \\
\text { endometriosis (187). }\end{array}$ \\
\hline MMP-2 & $\begin{array}{l}\text { Matrix } \\
\text { metalloproteinase-2 }\end{array}$ & $\begin{array}{l}\text { Polymorphisms in MMP-2 }(-735 \mathrm{C} / \mathrm{T}) \text { were associated with an elevated } \\
\text { risk of endometriosis (190). The MMP-2 G/6A haplotype may } \\
\text { modify susceptibility to endometriosis (187). The MMP-2 } \\
\text { polymorphisms are associated with advanced-stage } \\
\text { endometriosis (189). }\end{array}$ \\
\hline MMP-7 & $\begin{array}{l}\text { Matrix } \\
\text { metalloproteinase- } 7\end{array}$ & $\begin{array}{l}\text { MMP-7-181A/G polymorphism has the potential to be a susceptibility } \\
\text { factor for endometriosis in women from North China (191). }\end{array}$ \\
\hline MMP-9 & $\begin{array}{l}\text { Matrix } \\
\text { metalloproteinase-9 }\end{array}$ & $\begin{array}{l}\text { Polymorphisms in MMP-9 (-1562 C/T) were associated with } \\
\text { elevated risk of endometriosis (190). The haplotypes in the MMP-9 } \\
\text { gene may correlate with the progression of endometriosis (192). }\end{array}$ \\
\hline $\begin{array}{l}\text { MMP-12 and } \\
\text { MMP-13 }\end{array}$ & $\begin{array}{l}\text { Matrix } \\
\text { metalloproteinase-12 } \\
\text { and }-13\end{array}$ & $\begin{array}{l}\text { A potential role for MMP-12-82 A/G- and MMP-13-77 A/G-combined } \\
\text { polymorphisms was demonstrated in superficial } \\
\text { endometriosis (193). }\end{array}$ \\
\hline PAI-1 & $\begin{array}{l}\text { Plasminogen activator } \\
\text { inhibitor type- } 1\end{array}$ & $\begin{array}{l}\text { Hypofibrinolysis, associated with the } 4 \mathrm{G} \text { allele of the PAI- } 1 \text { gene, } \\
\text { was found significantly more often in women with endometriosis } \\
\text { compared with controls (195). The PAI- } 14 \mathrm{G} / 5 \mathrm{G} \text { polymorphism } \\
\text { may be associated with a risk of endometriosis-associated infertility } \\
\text { in Brazilian women (194). }\end{array}$ \\
\hline TIMP-2 & $\begin{array}{l}\text { Tissue inhibitor of } \\
\text { metalloproteinase } 2\end{array}$ & $\begin{array}{l}\text { The TIMP-2 - } 418 \mathrm{C} / \mathrm{C} \text { homozygote may be a protective factor against } \\
\text { the development of endometriosis in North Chinese women (196). } \\
\text { The TIMP-2 polymorphisms are associated with advanced-stage } \\
\text { endometriosis (189). }\end{array}$ \\
\hline
\end{tabular}

Growth factors

$\begin{array}{ll}\text { BDNF } & \begin{array}{l}\text { Brain-derived } \\ \text { neurotrophic factor }\end{array} \\ \text { EGFR } & \begin{array}{l}\text { Epidermal growth } \\ \text { factor receptor }\end{array} \\ \text { IGF-II } & \begin{array}{l}\text { Insulin-like } \\ \text { growth factor-II }\end{array} \\ & \text { Insulin-like } \\ \text { growth factor } \\ \text { binding protein 3 } \\ \text { Insulin receptor } \\ \text { substrate 2 } \\ \text { IRS2 }\end{array}$

The BDNF(Met) SNP may contribute to the increased susceptibility to Stage III-IV endometriosis and endometriosis-related infertility (197). BDNF is a member of the nerve growth factor family and is overexpressed in endometriosis.

EGFR gene 2073*T-related genotypes and allele are associated with higher susceptibilities to endometriosis (202).

The IGF-II $820 \mathrm{G} / \mathrm{A}$ polymorphism is a genetic factor that may be associated with the development of endometriosis in Korean women (198).

The AAG haplotype allele of the $-672 \mathrm{~A} / \mathrm{G},-202 \mathrm{~A} / \mathrm{C}$ and c $.95 \mathrm{C} / \mathrm{G}$ polymorphisms in the IGFBP3 gene may be associated with advanced endometriosis in Korean women (199).

The IRS2 1057G/D polymorphism may be associated with an increased risk for endometriosis (200).

NRIP1 gene variants might act as predisposing factors for endometriosis (179). NRIP1 gene modulates transcriptional activity of the estrogen receptor.

The VEGF -2578 A/C SNP may influence susceptibility to endometriosis in the Estonian population (206). The VEGF +936T/C polymorphism is capable of causing endometriosis susceptibility and is a risk factor for endometriosis (204). The CC genotype of VEGF +405 and 460T/405C haplotypes of VEGF may be associated with the risk of endometriosis (207). The VEGF-460/-1154/-2578 TGC, CAA, TAA and TAC haplotypes were associated with endometriosis. The -1154A and -2578A alleles may be protective against the development of endometriosis in North Chinese women (208). 
Table II. Continued.

Name Description Genetic polymorphisms and their haplotypes

VEGF Vascular endothelial growth factor

VEGFR-2 Vascular endothelial growth factor receptor-2

Cell cycle regulation, signaling and oncogenes

$\begin{array}{ll}\text { CDKN1B } & \text { Cyclin-dependent kinase } \\ & \text { inhibitor 1B (p27, Kip1) }\end{array}$

CDKN2BAS CDKN2B antisense RNA 1

$\begin{array}{ll}\text { KRAS } & \text { Kirsten rat sarcoma } \\ & \text { viral oncogene } \\ & \text { homolog }\end{array}$

PDCD6 Programmed cell death 6

$\begin{array}{ll}\text { PTPN22 } & \begin{array}{l}\text { Protein tyrosine } \\ \text { phosphatase }\end{array} \\ & \text { non-receptor type } 22 \\ & \text { (lymphoid) }\end{array}$

STAT6 Signal transducer and activator of transcription 6

TP53 Tumor protein p53
The $-460 \mathrm{~T} /+405 \mathrm{C}$ haplotype in the VEGF gene, which is associated with lower promoter activity, was significantly less common in women with endometriosis than in controls. These data suggest that the $+405 \mathrm{G}$ allele may influence the likelihood of a woman developing the disease (210). The VEGF $+405 \mathrm{C} / \mathrm{G}$ polymorphism may be associated with the risk of advanced stage endometriosis in the Korean population (209). The T/T homozygotes and the T allele of the VEGF-460 gene are associated with a higher risk of endometriosis (211). The VEGF +405 $\mathrm{G} / \mathrm{C}$ polymorphism is associated with the risk of endometriosis, and endometriosis associated with adenomyosis and chocolate cysts (203). The $+405 \mathrm{G} / \mathrm{C}$ polymorphism in VEGF may be associated with a higher risk of endometriosis in northern Iran (205).

The 1192C/T polymorphisms on the VEGFR-2 gene might affect the risk of developing endometriosis in Northern Chinese women of Han ethnicity (212).

The $109 \mathrm{~V} / \mathrm{G}$ polymorphism of the CDKN1B gene seems to be associated with a higher risk of the development of endometriosis (213).

CDKN2BAS is a new susceptibility locus for endometriosis (215). We confirm CDKN2BAS to be the first identified common loci for endometriosis (217).

An inherited polymorphism of a let-7 miRNA binding site in KRAS leads to abnormal endometrial growth and endometriosis. The KRAS let-7 (LCS6) polymorphism is the first described genetic marker of endometriosis risk (238).

PDCD6 gene may be a new susceptibility gene to endometriosis (216). PDCD6 participates in T cell receptor-, Fas-, and glucocorticoid-induced programmed cell death.

Female carriers of the PTPN22(*)T variant are significantly more susceptible to endometriosis than controls (218). In Brazilian women, the PTPN22 1858C/T polymorphism may be an important genetic predisposing factor for endometriosis, especially, in advanced disease (217). PTPN22 plays a role in the T-cell receptor signaling pathway. Mutations in this gene may be associated with a range of autoimmune disorders including type 1 diabetes, rheumatoid arthritis, systemic lupus erythematosus and Graves' disease.

The G2964A 3'-untranslated region polymorphism of the STAT6 gene is associated with endometriosis in South Indian women (225).

Specific TP53 polymorphisms are associated with an increased risk of endometriosis-associated infertility and with post-IVF failure (219). Genotype Pro/Pro of codon 72 polymorphism in TP53 contributes significantly to susceptibility to endometriosis in the Mexican population (122). The 16-bp duplication polymorphism in TP53 contributes significantly to susceptibility to endometriosis in the Mexican population (220). The TP53 codon 72 Pro/Pro + Arg/Pro genotypes are associated with increased risk of endometriosis in the Asian population (221). TP53 codon $72 *$ Pro-related genotype is related with a higher susceptibility of endometriosis (223). Endometriosis is associated with the TP53 polymorphism. p53 arginine homozygotes have a lower risk for endometriosis. Heterozygotes and proline homozygotes have a higher risk for endometriosis (224). 
Table II. Continued.

Name Description Genetic polymorphisms and their haplotypes
integration site family, member 4

Adhesion molecules

$\begin{array}{ll}\text { CDH1 } & \begin{array}{l}\text { Cadherin 1, } \\ \text { also known as } \\ \text { E-cadherin }\end{array}\end{array}$

FN1 Fibronectin 1

ICAM1 Intercellular adhesion molecule 1

MUC2 Mucin 2

MUC4 Mucin 4

Transcriptional regulation

CHD5 Chromodomain helicase

DNA binding protein 5

FOXP3 Forkhead box P3

HOXA10 Homeo box A10

PPARG Peroxisome proliferatoractivated receptor $\gamma$

PPARG2 Peroxisome proliferatoractivated receptor $\gamma 2$

Human leukocyte antigens

HLA-DQB1 Major histocompatibility, complex class II, DQ $\beta 1$
WNT4 Wingless-type MMTV

We confirm WNT4 as the first identified common loci for endometriosis (214). WNT4 is involved in oncogenesis and in several developmental processes, including the regulation of cell fate and patterning during embryogenesis.

The E-cadherin gene polymorphism rs4783689 was marginally associated with endometriosis in the Japanese population, suggesting that E-cadherin might be involved in genetic susceptibility to endometriosis (226). The E-cadherin $-347 \mathrm{GA} / \mathrm{GA}$ and $-160 \mathrm{~A} / \mathrm{A}$ genotypes and $-347 \mathrm{GA} /-160 \mathrm{~A} /+54 \mathrm{C}$ and $-347 \mathrm{G} /-160 \mathrm{~A} /+54 \mathrm{C}$ haplotypes may jointly modify the risk of endometriosis in Indian women (227). There is a relation between the CDH1 3'-UTR C/T polymorphism, the -160 A/-347 GA haplotype of two promoter polymorphisms and risk of endometriosis, suggesting a potential role in endometriosis development, at least in North Chinese women (228).

FN1 has been confirmed as the first identified common loci for endometriosis (214).

ICAM1 polymorphism in codon 241 is associated with the development of susceptibility to endometriosis in the population of northern Iran (229). IL-6 -634C/G and ICAM-1 469K/E polymorphisms synergistically affect the susceptibility for endometriosis in the Japanese population (126). A genetic polymorphism in the ICAM-1 gene domain may contribute to the susceptibility to endometriosis (246).

MUC2 polymorphisms, especially rs 10794288 and rs10902088, are associated with endometriosis as well as endometriosis-related infertility (230). MUC2 is a mucous barrier that protects the lumen.

MUC4 polymorphisms are associated with development of endometriosis and endometriosis-related infertility in the Taiwanese population (231).

Endometriosis may be associated with the tumor-suppressor gene CHD5 in the Caucasian population (232). CHD5 functions in chromatin remodeling and gene transcription. This gene is a potential tumor suppressor gene that may play a role in the development of neuroblastoma.

A possible FOXP3 and FCRL3 interaction leads to a cumulative effect on the development of endometriosis (115). FOXP3 is a member of the forkhead/winged-helix family of transcriptional regulators.

Patients with HOXA10 polymorphism were associated with a lower American Fertility Society score and less severe obliterated cul-de-sac (233).

The results suggest that the PPAR- $\gamma 161 \mathrm{CC}$ genotype may be a genetic risk factor for endometriosis (235).

The PPARG2 Pro12Ala polymorphism is associated with advanced-stage endometriosis in the Korean population (234). PPAR- $\gamma$ is a regulator of adipocyte differentiation. Additionally, PPAR- $\gamma$ is involved in the pathology of numerous diseases including obesity, diabetes, atherosclerosis and cancer.

The prevalence of the HLA-DQB $1 * 0301$ allele was significantly greater in patients with endometriosis, compared with the general controls (236). The HLA-DRB $1 * 1403$ allele may play a role in the development of endometriosis (237).

microRNAs

let-7

microRNA
An inherited polymorphism of a let-7 miRNA binding site in KRAS leads to abnormal endometrial growth and endometriosis. The KRAS let-7 (LCS6) polymorphism is the first described genetic marker of endometriosis risk (238). 
Table II. Continued.

\begin{tabular}{|c|c|c|}
\hline Name & Description & Genetic polymorphisms and their haplotypes \\
\hline \multicolumn{3}{|l|}{ Others } \\
\hline $\mathrm{ACE}$ & $\begin{array}{l}\text { Angiotensin I converting } \\
\text { enzyme }\end{array}$ & $\begin{array}{l}\text { ACE*I/D gene polymorphisms are associated with endometriosis (239) } \\
\text { ACE } 2350 * \text { G and ACE-240*T-related genotypes and alleles are } \\
\text { associated with higher susceptibility to endometriosis (240). }\end{array}$ \\
\hline AHSG & $\begin{array}{l}\alpha \text {-2-Heremans Schmidt } \\
\text { (HS)-glycoprotein }\end{array}$ & $\begin{array}{l}\text { Endometriosis is associated with the AHSG gene polymorphism in } \\
\text { Korean women (241). AHSG is involved in several functions, such as } \\
\text { endocytosis, brain development and the formation of bone tissue. }\end{array}$ \\
\hline $\mathrm{C} 3$ & $\begin{array}{l}\text { Complement } \\
\text { component } 3\end{array}$ & $\begin{array}{l}\text { Statistically significant differences in the allelic frequencies and } \\
\text { genotype distribution of genetic variants in LOXL4 and C } 3 \text { were } \\
\text { documented in patients with endometriosis-associated infertility } \\
\text { versus controls, and in patients with endometriosis versus controls, } \\
\text { respectively, in a Puerto Rican population (185). }\end{array}$ \\
\hline DNMT3L & $\begin{array}{l}\text { DNA (cytosine-5)- } \\
\text { methyltransferase } 3 \text {-like }\end{array}$ & $\begin{array}{l}\text { The association of DNMT3L genetic variants and endometrioma was } \\
\text { detected (242). DNMT3L stimulates de novo methylation by DNA } \\
\text { cytosine methyltransferase } 3 \alpha \text { and is thought to be required for } \\
\text { the establishment of maternal genomic imprints. }\end{array}$ \\
\hline GALT & $\begin{array}{l}\text { Galactose-1-phosphate } \\
\text { uridylyltransferase }\end{array}$ & $\begin{array}{l}\text { Loss of heterozygosity on GALT occurs in endometriosis (35). The } \\
\text { N314D mutation of GALT is associated with endometriosis (53). }\end{array}$ \\
\hline MTHFR & $\begin{array}{l}\text { Methylenetetrahydrofolate } \\
\text { reductase }(\mathrm{NAD}(\mathrm{P}) \mathrm{H})\end{array}$ & $\begin{array}{l}\text { The exhaustive multifactor dimensionality reduction analysis revealed } \\
\text { an epistatic interaction between rs } 1801133 \text { of MTHFR and rs } 4244593 \\
\text { of PEMT in endometriosis-associated infertility ( } 243) \text {. }\end{array}$ \\
\hline PEMT & $\begin{array}{l}\text { Phosphatidylethanolamine } \\
\text { N-methyltransferase }\end{array}$ & $\begin{array}{l}\text { MTHFR is a co-substrate for homocysteine remethylation to } \\
\text { methionine. PEMT converts phosphatidylethanolamine to } \\
\text { phosphatidylcholine by sequential methylation. }\end{array}$ \\
\hline SLC22A23 & $\begin{array}{l}\text { Solute carrier family } 22, \\
\text { member } 23 \text {, transports } \\
\text { organic ions across } \\
\text { cell membranes }\end{array}$ & $\begin{array}{l}\text { Significant associations between SLC22A23 haplotypes and the severe } \\
\text { stage of the disease were identified (244). }\end{array}$ \\
\hline WHSC1 & $\begin{array}{l}\text { Wolf-Hirschhorn } \\
\text { syndrome candidate } 1\end{array}$ & $\begin{array}{l}\text { Significant associations between WHSC1 alleles and endometriosis- } \\
\text { related infertility were identified (244). Wolf-Hirschhorn syndrome } \\
\text { (WHS) is a malformation syndrome associated with a hemizygous } \\
\text { deletion of the distal short arm of chromosome } 4 \text {. }\end{array}$ \\
\hline
\end{tabular}

normal endometriosis development to preneoplastic atypical lesions. Genes responsible for the malignant transformation of endometriosis include AT-rich interactive domain 1A (SWI-like) (ARID1A) $(3,15,17-19)$, tumor protein p53 (TP53) $(3,10,30,64,65), \mathrm{v}-$ raf murine sarcoma viral oncogene homolog $\mathrm{B}$ (BRAF) $(63,66,67)$, phosphatidylinositol-4,5-bisphosphate 3-kinase, catalytic subunit $\alpha$ (PIK3CA) $(16,17,68)$, actinin, $\alpha 4$ (ACTN4) (69), telomerase reverse transcriptase (TERT) (70), mindbomb E3 ubiquitin protein ligase 1 (MIB1) (49), v-erb-b2 avian erythroblastic leukemia viral oncogene homolog 2, also known as HER2 (ERBB2) (71), cyclin-dependent kinase inhibitor 1A (p21, Cip1) (CDKN1A) (50,72-74) and met protooncogene (MET) (75).

Gene candidates responsible for cancer progression. These genes are associated with an increased susceptibility to ovarian carcinomas, through transition from atypical endometriosis to carcinoma. Sequential progression from benign endometriosis to atypical forms culminates in neoplasia in endometriosisassociated ovarian carcinoma. Genes responsible for cancer progression include Kirsten rat sarcoma viral oncogene homolog (KRAS) (76).

Benign, solitary endometriosis has shown somatic mutations in the PTEN and XRCC genes, but may be uncommon in ARID1A, TP53 and KRAS gene mutations. Endometriotic lesions adjacent to carcinomas have loss- or gain-of-function mutations, amplifications or overexpression in genes and proteins directly related to neoplasms, in particular the PTEN, ARID1A, MYC, TP53, CTNNB1 and PIK3CA genes. KRAS mutations may be associated with the malignant transformation of atypical endometriosis into ovarian carcinomas (76).

\section{Mitochondrial DNA (mtDNA) mutations}

Somatic mitochondrial DNA (mtDNA) mutations have been regarded as a hallmark of neoplasms and chronic inflammatory 
Table III. Information concerning endometriosis susceptibility genes, genes responsible for tumor promotion and genes responsible for malignant transformation of endometriosis and cancer progression.

\begin{tabular}{|c|c|c|c|}
\hline \multirow[b]{2}{*}{ Genes } & \multirow[b]{2}{*}{$\begin{array}{l}\text { Endometriosis } \\
\text { susceptibility } \\
\text { genes }\end{array}$} & \multicolumn{2}{|c|}{$\begin{array}{l}\text { Genes responsible for } \\
\text { tumor promotion }\end{array}$} \\
\hline & & $\begin{array}{l}\text { Genes responsible } \\
\text { for malignant } \\
\text { transformation } \\
\text { of endometriosis }\end{array}$ & $\begin{array}{l}\text { Genes } \\
\text { responsible for } \\
\text { cancer } \\
\text { progression }\end{array}$ \\
\hline PTEN & $-/+$ & + & + \\
\hline MYC & + & ND & + \\
\hline CTNNB1 & $-/+$ & ND & + \\
\hline XRCC & + & ND & ND \\
\hline BCL2 & $-/+$ & $-/+$ & + \\
\hline GALT & + & ND & + \\
\hline GSTM1 & + & ND & + \\
\hline ARID1A & - & + & + \\
\hline TP53 & - & + & + \\
\hline BRAF & - & ND & - \\
\hline PIK3CA & - & + & + \\
\hline ACTN4 & - & + & + \\
\hline TERT & - & + & + \\
\hline MIB1 & - & + & + \\
\hline ERBB2 & - & ND & + \\
\hline CDKN1A & ND & ND & + \\
\hline MET & - & + & + \\
\hline KRAS & - & - & + \\
\hline
\end{tabular}

ND, not determined.

diseases such as aging, neurodegenerative disease and endometriosis (77). mtDNA is highly vulnerable to mutagenesis through the production of ROS. Specific mtDNA mutations also increase ROS overproduction and enhance tumor progression. Several types of mtDNA alterations, including point mutations, deletions, insertions and copy number changes, have been associated with carcinogenesis (78). Findings of previous studies have demonstrated the possible association between mtDNA polymorphisms and susceptibility to endometriosis, including A189G, A13603G, 310C insertion, T16189C polymorphisms, 189G/310TC/16189C haplotype, and 5,335-bp deletion (77,79-81). Therefore, mtDNA genetic alterations may exhibit risk of endometriosis development. No evidence has emerged indicating that these mtDNA mutations are functional and pathogenic.

\section{Epigenetic alterations}

Beyond genetic/genomic alterations, the development of endometriosis is also influenced by epigenetic mechanisms. Accumulating evidence suggest various epigenetic aberrations in endometriosis $(6,82)$. Epigenetic alterations reported in endometriosis thus far include the genomic DNA methylation of progesterone receptor (PGR)-B, E-cadherin (CDH1), homeobox A10 (HOXA10) (83), estrogen receptor- $\beta$ (ESR2), aromatase (CYP19A1) (84), histone deacetylase inhibition (HDACi) (82), CDKN2A/B (85), IGFBP-1 (83), leukemia inhibitory factor (LIF) (83) and DNA-methyltransferase (DNMTs) (86). Downregulated genes are associated with embryogenesis (the downstream targets of HOXA10), growth factors (IGF and IGFBP) and immuno-endocrine behavior [prolactin (PRL)], interleukin-11 (IL-11), leukemia inhibitory factor (LIF), transforming growth factor (TGF)- $\beta$, FK506 binding protein 4, $59 \mathrm{kDa}$ (FKBP4), cyclooxygenase (COX)-2, prostaglandins (PGs), forkhead box O1 (FOXO1) and CCAAT/ enhancer binding protein (C/EBP), $\beta$ (C/EBP $\beta)(6,82,84-94)$. Target genes are important for the embryogenesis and decidualization process, which includes hormonal regulation, cytokine expression and transcription factors $(89,95)$. A previous study has shed new light on the overlapping epigenetic signatures between the development of endometriosis and insufficient decidualization process (89). Large-scale epigenetic silencing of decidualization-related genes might play important roles in the development of endometriosis (95).

\section{Epidemiology}

Endometriosis has been successfully identified a novel geneenvironment interaction (96). Previous studies have described a positive relationship and inverse association between endometriosis risk and social, environmental and biological factors, as well as their interactions (97-107). Factors contributing to an increased risk are low birth weight, a multiple gestation, exposure to diethylstilbestrol in utero (97), overweight during late childhood (106), level of indoor exposure to passive smoking during childhood, experiencing food deprivation during World War II, walking activity at 8-15 years of age, exposure to pet animals, living in a farm for $\geq 3$ consecutive months during childhood (100), a flight attendant, service station attendant, or health worker, a nurse (105), night shift work (107), alcohol consumption (98), cutaneous melanoma, skin sensitivity to sun exposure, nevi, freckles (108), pigmentary traits, family history of melanoma, periodontal disease (107), and caesarean section (99). On the other hand, a decreased risk of endometriosis is associated with the factors such as menarcheal age (100), increasing body size during childhood and early adulthood (102), body mass index, longchain omega-3 fatty acid consumption (101), and in utero cigarette exposure (108). Results of those studies suggest that specific adverse exposures throughout fetal life, in early life, or during childhood or adolescence may influence the risk of endometriosis (100). Evidence of endometriosis risk of dioxin is not sufficient and remains limited (103). Based on insufficient data, it is currently not clear whether each factor is a true characteristic of women who develop endometriosis (106).

\section{Discussion}

Endometriosis is a chronic inflammatory disease with genetic, epigenetic and environmental background (109). Firstly, independent analysis of many cohorts have suggested genetic/epigenetic alterations such as SNPs, copy number 
Table IV. Epigenetically and genetically relevant information of endometriosis susceptibility genes, genes responsible for tumor promotion and genes responsible for malignant transformation of endometriosis and cancer progression.

Name Description Characteristics and functions

Endometriosis susceptibility genes

PTEN Phosphatase and tensin homolog

MYC v-myc avian myelocytomatosis viral oncogene homolog

CTNNB1 Catenin (cadherinassociated protein), $\beta 1,88 \mathrm{kDa}$

XRCC

X-ray repair complementing defective repair in Chinese hamster cells

BCL2

B-cell

CLL/lymphoma 2
Tumor suppressor gene PTEN, located on chromosome 10q23.3, is frequently deleted in human carcinomas. PTEN is a negative regulator of the PIK3/Akt survival signaling pathway. No PTEN mutations were identified in normal endometrium, endometriosis and atypical endometriosis (28). However, it has been demonstrated that somatic mutations in the PTEN gene have been associated with $20-30 \%$ of solitary endometrial cysts $(27,36)$. Genetic mutations leading to functional inactivation of the PTEN gene were identified in one third of ovarian carcinomas $(23,27)$. An increased frequency of the PTEN gene mutations has been reported in endometrioid carcinoma, but not in clear cell or serous tumors $(3,30)$. These data suggest that somatic PTEN gene mutations play a part in the development of endometriosis itself and mainly malignant transformation of endometriosis.

The protein encoded by this gene is associated with important aspects of tumor biology including the regulation of cell growth and proliferation, cell adhesion, metabolism, differentiation, apoptosis, and angiogenesis. Mutations, overexpression, rearrangement and translocation of the MYC gene have been associated with a variety of hematopoietic tumors, leukemias and lymphomas. The gene expression levels were increased in ectopic tissue in comparison with normal and eutopic endometrium (40). MYC amplifications have been observed in ovarian carcinomas, particularly in endometriosis-associated endometrioid adenocarcinomas (39). The MYC amplifications possibly reflect the importance for initiation and/or progression of the development of endometriosis itself and mainly endometrioid adenocarcinomas.

Both loss- and gain-of-function mutations of $\beta$-catenin have been established as the driving force of tumorigenesis in many carcinomas (44). Aberrant activation of the Wnt/ß-catenin signaling pathway can generate chromosomal instability (44). Although there are no genetic mutation analyses, endometriotic tissues exhibited markedly reduced staining when compared with proliferative endometrium (43). Shaco-Levy et al reported that immunophenotypic abnormalities were present in $23 \%$ of histologically benign endometriotic lesions (43). The CTNNB1 gene mutations were detected in low-grade endometrioid carcinomas (41), suggesting that endometrioid carcinomas arise from endometriosis via CTNNB1 gene mutations. Common genetic alterations may therefore be a dependent event from endometriosis to endometrioid carcinoma that are consistent with a common lineage (30).

XRCC1 is essential for DNA base excision repair, single-strand break repair and nucleotide excision repair. Oxidative DNA damage due to chronic inflammatory stimuli and oxidative stress due to lower DNA repair activity are associated with endometriosis progression (47). Several polymorphisms in the DNA repair gene, the genotypes of XRCC1 Arg/Gln and XRCC3 Thr/Thr, are associated with endometriosis risk $(45,46)$, demonstrating somatic XRCC gene mutations in endometriosis risk. Defective DNA repair generates chromosomal instability that can cause subsequent alterations in gene expression. XRCC1 expression was also associated with serous type ovarian carcinomas. This gene is a predictive biomarker in ovarian carcinomas, but not a carcinoma susceptibility gene (48).

No genetic BCL2 mutations have been reported in endometriosis. Immunohistochemical studies demonstrated that anti-apoptotic factor Bcl-2 was reported to stain $23 \%$ of benign endometriotic cysts, $42 \%$ of benign endometriotic lesions adjacent to the endometrioid carcinoma, $67 \%$ of endometrioid carcinomas, $73 \%$ of clear cell carcinomas, and $50 \%$ of papillary serous carcinomas (51).

No differences have been previously found in the expression of Bcl-2 in endometriosis and ovarian carcinomas $(49,50)$. 
Table IV. Continued.

\begin{tabular}{lll} 
Name & \multicolumn{1}{c}{ Description } & \multicolumn{1}{c}{ Characteristics and functions } \\
\hline GALT & $\begin{array}{l}\text { Galactose-1-phosphate } \\
\text { uridylyltransferase } \\
9 p 13\end{array}$ & $\begin{array}{l}\text { N314D mutation of GALT gene revealed a significant association with } \\
\text { endometriosis patients compared to general population controls } \\
(30 \% \text { compared with 14\%) (53). However, findings of recent reports provide } \\
\text { no evidence supporting involvement of the GALT locus in the development of } \\
\text { endometriosis (54,55). GALT locus is a region frequently lost in ovarian } \\
\text { carcinomas (35). }\end{array}$ \\
& $\begin{array}{l}\text { GSTM1 and NAT2 (genes encoding for the detoxification enzymes) act as possible } \\
\text { GSTM1 }\end{array}$ & $\begin{array}{l}\text { disease susceptibility genes. GSTM1 null type was associated with a significantly } \\
\text { increased risk of endometriosis [odds ratio (OR)=2.38] (see 'A SNP haplotype } \\
\text { analysis' section). }\end{array}$
\end{tabular}

Genes responsible for malignant transformation of endometriosis

$\begin{array}{ll}\text { ARID1A } & \text { AT rich interactive } \\ & \text { domain 1A (SWI-like) }\end{array}$

TP53 Tumor protein p53

BRAF $\quad$-raf murine sarcoma viral oncogene homolog B

PIK3CA Phosphatidylinositol-4,5bisphosphate 3-kinase, catalytic subunit $\alpha$

ACTN4 Actinin, $\alpha 4$

TERT Telomerase reverse transcriptase protein ligase 1
ARID1A modulates the chromatin remodeling complex, through interactions with p53, SMAD family member 3 (SMAD3), or hormonal receptors. This complex plays a role in a variety of DNA activities such as replication, repair, methylation, recombination, transcription and gene expression by regulating key chromatin functions (246). ARID1A is frequently mutated in a variety of human cancers $(15,17,18)$. Immunohistochemistry showed that a high frequency of the negative expression of ARID1A was $86-100 \%$ of the cases, including endometriotic cyst epithelium of non-atypical endometriosis, atypical endometriosis, the endometriotic lesions adjacent to carcinomas with deficient ARID1A expression (15). On the other hand, endometriosis distant from ARID1A-deficient carcinomas and solitary endometriosis were positive for ARID1A $(15,19)$. Mutation of ARID1A seems to be an early event, which develops at the stage of endometriosis and is reliably detectable in the precursor lesion (3).

TP53 genetic alterations were absent in solitary endometriosis (64). Ovarian carcinomas and adjacent endometriotic lesions have shown TP53 gene mutations, suggesting a possible malignant genetic transition spectrum $(3,10)$. The TP53 gene alterations were not seen in endometriotic lesions that were distant from each other (30). The mutations were positive in $31 \%$ of endometriosis coexisting with clear cell carcinoma, whereas no mutations were detected in endometriosis coexisting with endometrioid adenocarcinoma (65). High-grade serous and possibly endometrioid carcinomas probably arise from cells with TP53 mutations and possibly the dysfunction of BRCA1 and/or BRCA2.

Genomic data are limited. BRAF mutations are rare in endometriosis (63). BRAF mutations do not have an essential role in endometriosis-associated and endometriosis-independent endometrioid adenocarcinoma (66). It was recognized that low-grade serous carcinomas are characterized by BRAF mutations (67).

Several studies have reported PI3K/AKT pathway activation in the solitary endometriosis (17), but no PIK3CA gene mutations were detected (68). PIK3CA activating H1047R mutations have been reported to show a high sensitivity for ovarian clear cell carcinoma (33-46\%) (16). Same mutations were frequently found in the endometriotic epithelium adjacent to clear cell carcinomas (16). $\alpha$ actinin is an actin-binding protein. ACTN4 mutations, gains of ACTN4, or actinin-4 overexpression are not detected in endometriosis (69). More than half of the atypical endometrioses exhibited low-level gains of ACTN4 and actinin-4 overexpression (69).

Current knowledge on TERT gene mutations is very limited. Somatic gain-of-function mutations at the TERT promoter act as one of the mechanisms of ovarian clear cell carcinogenesis (70). TERT gene mutations were not detected in the endometriotic lesions adjacent to the clear cell carcinoma, suggesting that they do not appear to be an early event in the carcinogenic sequence.

MIB1 functions as an E3 ubiquitin ligase. The encoded protein may promote the ubiquitination and degradation of death-associated protein kinase 1 (DAPK1), 
Table IV. Continued.

\begin{tabular}{|c|c|c|}
\hline Name & Description & Characteristics and functions \\
\hline MIB1 & $\begin{array}{l}\text { Mindbomb E3 ubiquitin } \\
\text { protein ligase } 1\end{array}$ & $\begin{array}{l}\text { an apoptosis-related tumor suppressor gene. A high expression of MIB1 protein } \\
\text { was detected in high-grade ovarian carcinoma and atypical endometriosis (49). } \\
\text { Transitions from atypical endometriosis to carcinoma may be documented. }\end{array}$ \\
\hline ERBB2 & $\begin{array}{l}\text { v-erb-b2 avian } \\
\text { erythroblastic leukemia } \\
\text { viral oncogene homolog } 2 \text {, } \\
\text { also known as HER2 }\end{array}$ & $\begin{array}{l}\text { c-erb-B2 is a member of the epidermal growth factor (EGF) receptor family of } \\
\text { receptor tyrosine kinases. No expression of c-erb B2 protein was detected in } \\
\text { endometriotic tissues, suggesting that ERBB2 gene may not play an important } \\
\text { role in the physiopathology of endometriosis. The overexpression of c-erb-B2 } \\
\text { protein was found in endometriosis-related endometrioid adenocarcinomas (71). } \\
\text { Genomic data are limited. }\end{array}$ \\
\hline CDKN1A & $\begin{array}{l}\text { Cyclin-dependent } \\
\text { kinase inhibitor } 1 \mathrm{~A} \\
(\mathrm{p} 21, \mathrm{Cip} 1)\end{array}$ & $\begin{array}{l}\text { This gene encodes a potent cyclin-dependent kinase inhibitor. p21, a downstream } \\
\text { effector of ARID1A. No difference was detected in the distribution of the } \\
\text { CDKN1A genotype between the endometriosis and control groups }(72) \text {. } \\
\text { Increased p21 expression was found in endometriosis and ovarian clear cell } \\
\text { carcinoma }(50,73,74) \text {. Genomic data are limited. }\end{array}$ \\
\hline MET & met proto-oncogene & $\begin{array}{l}\text { The proto-oncogene MET product is the hepatocyte growth factor receptor and } \\
\text { encodes tyrosine-kinase activity. The results of previous studies revealed } \\
\text { amplification of the MET gene and overexpression of the MET protein, especially } \\
\text { in ovarian clear cell carcinoma (75). Endometriosis is negative for MET gain (75). } \\
\text { A step-wise increase in MET levels was noted from paired endometriosis }(0 \%) \text {, } \\
\text { to atypical endometriosis }(67 \%) \text { and clear cell carcinoma }(>90 \%)(75) \text {. MET } \\
\text { gain predisposes to the malignant transformation of endometriosis and might } \\
\text { cause the development and progression of clear cell carcinoma (75). }\end{array}$ \\
\hline \multicolumn{3}{|c|}{ Genes responsible for cancer progression } \\
\hline KRAS & $\begin{array}{l}\text { Kirsten rat sarcoma } \\
\text { viral oncogene } \\
\text { homolog }\end{array}$ & $\begin{array}{l}\text { KRAS is one of the most important downstream effectors coupling epidermal } \\
\text { growth factor receptor (EGFR) to intracellular signaling cascades, leading to } \\
\text { cell growth and inhibition of apoptosis. KRAS gene mutations were detectable } \\
\text { in clear cell carcinoma, endometrioid adenocarcinoma and mucinous } \\
\text { adenocarcinoma (76). KRAS mutations were not detected in endometriosis } \\
\text { or atypical endometriosis bordering the cancerous region }(20,42) \text {. It is possible } \\
\text { that KRAS mutations are associated with malignant transformation of } \\
\text { atypical endometriosis into ovarian carcinomas (76). }\end{array}$ \\
\hline
\end{tabular}

variation, loss of heterozygosity, and promoter methylation on the development of endometriosis (Table I). Polymorphic variants of the specific alleles were found to exhibit a significant positive or inverse association between the risk for endometriosis compared to the controls. Genome-wide gene expression profiling studies (88) showed that differentially regulated (ectopic-to-eutopic) genes in endometriosis were classified into several functional categories, including inflammation and immune response, cell cycle regulation, cytokine and growth factor signaling, endocrine function, matrix remodeling, cell adhesion, DNA damage and detoxification, regulation of glucose and lipid metabolism and transcription factors (88). These data allow us to hypothesize that the previously reported endometriosis susceptibility genes (88) tend to overlap those with genetic polymorphisms analyzed in this study (Tables I and II).

Many susceptibility genes have been reported as candidate genes for the development of endometriosis. However, a majority of genes are not key drivers of somatic expansion, but likely candidate modifiers that bridge inflammation, detoxification, growth and immune escape to license eutopic and ectopic outgrowth. Epistatic modifier genes are known to participate in a wide range of essential processes: one such mechanism is inflammation and oxidative stress $(2,7,8,10,110,111)$. This finding supports the previous hypothesis that iron-induced oxidative stress and detoxification seems to play a key role in the development of endometriosis (2). Many modifier genes are considered to complement the actions of causative genes and play a significant role in variable phenotypic expression of the disease. Although genetic alterations inherited from parents confers susceptibility to endometriosis, wide variations in the penetrance of gene mutations may reflect the genetic background of the phenotypic diversity. Variable penetrance reflects the action of modifier genes. Even particular mutations or their variant transcripts associated with disease onset may fail to cause endometriosis, due to reduced or incomplete penetrance. Despite the identification of mutations associated with the development of endometriosis, the precise functional genetic alterations remain poorly understood. 
Secondly, the epigenetic disruption of gene expression also plays an important role in the development of endometriosis through interaction with environmental changes. The 'thrifty phenotype hypothesis' demonstrated that maternal diet during fetal development has many epigenetic implications, which affect the offspring's risk factors for obesity during childhood and adulthood, and even in subsequent generations (112). Similar adverse effects may be seen in other aspects of biological functions such as endometriosis. Low birthweight and multiple pregnancy are associated with subsequent endometriosis risk (97). Specific adverse environmental exposures in fetal and neonatal life, in childhood or adolescence may influence the risk of endometriosis (100). A recent study showed that environmental changes in utero such as maternal dietary energy intakes or prenatal exposures induce altered epigenetic regulation in the offspring affecting the expression of specific modifier genes that are mainly associated with endometrial decidualization processes $(89,95)$. Epigenetic alterations may be associated with altered tissue function in fetal endometrium and influence later-life disease. The developmental origins of health and disease $(\mathrm{DOHaD})$ approach may be used to elucidate the pathogenesis and epigenetic alterations of endometriosis. If gene mutations associated with endometrial decidualization are susceptible to epigenetic alterations, they have subsequent effects on disease mechanisms, such as impaired decidualization and endometriosis $(89,95)$. The demonstration of such a sequence of genetic and epigenetic events has been shown for disease processes such as obesity, metabolic syndrome and type 2 diabetes, cardiovascular disease, cancer and possibly endometriosis. Gene-environment interactions can promote the acquisition of epigenetic alterations, genetic mutations and a different profile of gene expression. However, the precise link between epigenetics and disease is missing. The regulation of these processes in which the individuals more predisposed to endometriosis remain to be elucidated.

Mounting evidence suggests that women with endometriosis have a higher risk for ovarian cancer. In this study, ovarian cancer susceptibility genes have been defined as candidate genes responsible for malignant transformation (from endometriosis to atypical endometriosis) and candidate genes responsible for cancer progression (from atypical endometriosis to ovarian cancer) (Tables III and IV). A majority of genes function as genes responsible for malignant transformation.

Environmental factors including iron, redox and inflammatory modifications may originate from retrograde menstruation and accumulate in endometriotic lesions. Iron is an extremely reactive transition metal and generates hydroxyl radicals via a Fenton reaction $(2,3,7-10,18)$. It is well known that iron is involved in a wide range of oxidative stress, and iron accumulation introduces point mutations as well as DNA single and double-strand breaks (110). Iron overload can also cause genetic and epigenetic changes, including DNA hypermethylation and chromatin remodeling, which lead to genomic instability and a significant increase in cancer risk $(2,109,110,113)$. Iron contributes to carcinogenesis via three major processes: step one, by generating iron-mediated oxidative stress (genetic/epigenetic changes); step two, by promoting DNA mutagenesis, histone modification, chromatin remodeling (EAOC initiation); and step three, by enhancing genome instability (cancer promotion and progression) (111).
In conclusion, genetic and genomic factors have been unable to explain the full etiology of endometriosis. It is tempting to hypothesis that there are at least three distinct phases of the development of endometriosis: the initial wave of genetic background inherited from parents; followed by epigenetic modifications in the female offspring; and the iron overload, which is subject to dynamic modulation later in life. Stress in utero or during adolescence may compromise the future oxidative stress response to an iron insult. The present study may provide new insights into the potential mechanisms by which microenvironmental changes such as iron overload induces endometriosis and enhances endometriosis-associated carcinogenesis. Future investigations should focus on how such epigenetic changes continue to regulate risk of endometriosis from infancy through to adulthood. For example, hypermethylation of the decidualization-related genes in fetal life may cause a decrease in expression, and have a direct impact on uterine endometrial functions such as decidualization, thus influencing risk of endometriosis and infertility later in life. Of note, specific (epi)genetic signatures have led to emerging efforts to apply the knowledge to early detection, diagnosis and development of molecularly targeted therapy.

\section{Acknowledgements}

The present review was supported by a grant-in-aid for the Scientific Research from the Ministry of Education, Science, and Culture of Japan to the Department of Obstetrics and Gynecology, Nara Medical University (to H.K.).

\section{References}

1. Forte A, Cipollaro M and Galderisi U: Genetic, epigenetic and stem cell alterations in endometriosis: new insights and potential therapeutic perspectives. Clin Sci (Lond) 126: $123-138,2014$

2. Kobayashi H, Yamada Y, Kanayama S, et al: The role of iron in the pathogenesis of endometriosis. Gynecol Endocrinol 25: 39-52, 2009.

3. Munksgaard PS and Blaakaer J: The association between endometriosis and ovarian cancer: a review of histological, genetic and molecular alterations. Gynecol Oncol 124: 164-169, 2012.

4. Vlahos NF, Kalampokas T and Fotiou S: Endometriosis and ovarian cancer: a review. Gynecol Endocrinol 26: 213-219, 2010.

5. Congrains A, Kamide K, Ohishi M and Rakugi H: ANRIL: molecular mechanisms and implications in human health. Int J Mol Sci 14: 1278-1292, 2013.

6. Guo SW: Epigenetics of endometriosis. Mol Hum Reprod 15: 587-607, 2009.

7. Van Langendonckt A, Casanas-Roux F and Donnez J: Oxidative stress and peritoneal endometriosis. Fertil Steril 77: 861-870, 2002.

8. Oner-Iyidoğan Y, Koçak H, Gürdöl F, Korkmaz D and Buyru F: Indices of oxidative stress in eutopic and ectopic endometria of women with endometriosis. Gynecol Obstet Invest 57: 214-217, 2004.

9. Ngô C, Chéreau C, Nicco C, Weill B, Chapron C and Batteux F: Reactive oxygen species controls endometriosis progression. Am J Pathol 175: 225-234, 2009.

10. Nezhat F, Datta MS, Hanson V, Pejovic T, Nezhat C and Nezhat C: The relationship of endometriosis and ovarian malignancy: a review. Fertil Steril 90: 1559-1570, 2008.

11. Kennedy S: Genetics of endometriosis: a review of the positional cloning approaches. Semin Reprod Med 21: 111-118, 2003.

12. Spuijbroek MD, Dunselman GA, Menheere PP and Evers JL: Early endometriosis invades the extracellular matrix. Fertil Steril 58: 929-933, 1992. 
13. Worley MJ, Welch WR, Berkowitz RS and Ng SW: Endometriosisassociated ovarian cancer: a review of pathogenesis. Int J Mol Sci 14: 5367-5379, 2013.

14. Higashiura Y, Kajihara H, Shigetomi $\mathrm{H}$ and Kobayashi $\mathrm{H}$ : Identification of multiple pathways involved in the malignant transformation of endometriosis (Review). Oncol Lett 4: 3-9, 2012.

15. Mao TL and Shih IM: The roles of ARID1A in gynecologic cancer. J Gynecol Oncol 24: 376-381, 2013.

16. Yamamoto S, Tsuda $\mathrm{H}$, Takano $\mathrm{M}$, Iwaya $\mathrm{K}$, Tamai $\mathrm{S}$ and Matsubara O: PIK3CA mutation is an early event in the development of endometriosis-associated ovarian clear cell adenocarcinoma. J Pathol 225: 189-194, 2011.

17. Samartzis EP, Noske A, Dedes KJ, Fink D and Imesch P: ARID1A mutations and PI3K/AKT pathway alterations in endometriosis and endometriosis-associated ovarian carcinomas. Int J Mol Sci 14: 18824-1849, 2013.

18. Maeda D and Shih IeM: Pathogenesis and the role of ARID1A mutation in endometriosis-related ovarian neoplasms. Adv Anat Pathol 20: 45-52, 2013.

19. Wiegand KC, Shah SP, Al-Agha OM, et al: ARID1A mutations in endometriosis-associated ovarian carcinomas. N Engl J Med 363: 1532-1543, 2010.

20. Amemiya S, Sekizawa A, Otsuka J, Tachikawa T, Saito H and Okai T: Malignant transformation of endometriosis and genetic alterations of K-ras and microsatellite instability. Int J Gynaecol Obstet 86: 371-376, 2004

21. Nakayama K, Toki T, Nikaido T, Zhai YL and Konishi I: Genetic alterations in microsatellite marker sites among tumor suppressor genes in endometriosis. Gynecol Obstet Invest 51: 240-242, 2001.

22. Fuseya C, Horiuchi A, Hayashi A, et al: Involvement of pelvic inflammation-related mismatch repair abnormalities and microsatellite instability in the malignant transformation of ovarian endometriosis. Hum Pathol 43: 1964-1972, 2012.

23. Ali-Fehmi R, Khalifeh I, Bandyopadhyay S, et al: Patterns of loss of heterozygosity at 10q23.3 and microsatellite instability in endometriosis, atypical endometriosis, and ovarian carcinoma arising in association with endometriosis. Int $\mathrm{J}$ Gynecol Pathol 25: 223-229, 2006.

24. Gogusev J, Bouquet de Jolinière J, Telvi L, et al: Genetic abnormalities detected by comparative genomic hybridization in a human endometriosis-derived cell line. Mol Hum Reprod 6: $821-827,2000$

25. Yang W, Zhang Y, Fu F and Li R: High-resolution arraycomparative genomic hybridization profiling reveals $20 \mathrm{q} 13.33$ alterations associated with ovarian endometriosis. Gynecol Endocrinol 29: 603-607, 2013.

26. Saare M, Sõritsa D, Vaidla K, et al: No evidence of somatic DNA copy number alterations in eutopic and ectopic endometrial tissue in endometriosis. Hum Reprod 27: 1857-1864, 2012.

27. Sato N, Tsunoda H, Nishida M, et al: Loss of heterozygosity on 10q23.3 and mutation of the tumor suppressor gene PTEN in benign endometrial cyst of the ovary: possible sequence progression from benign endometrial cyst to endometrioid carcinoma and clear cell carcinoma of the ovary. Cancer Res 60: 7052-7056, 2000.

28. Obata K and Hoshiai H: Common genetic changes between endometriosis and ovarian cancer. Gynecol Obstet Invest 50 (Suppl 1): 39-43, 2000.

29. Xu B, Hamada S, Kusuki I, Itoh R and Kitawaki J: Possible involvement of loss of heterozygosity in malignant transformation of ovarian endometriosis. Gynecol Oncol 120: 239-246, 2011.

30. Thomas EJ and Campbell IG: Molecular genetic defects in endometriosis. Gynecol Obstet Invest 50 (Suppl 1): 44-50, 2000

31. Painter JN, Anderson CA, Nyholt DR, et al: Genome-wide association study identifies a locus at 7p15.2 associated with endometriosis. Nat Genet 43: 51-54, 2011.

32. Jiang X, Hitchcock A, Bryan EJ, et al: Microsatellite analysis of endometriosis reveals loss of heterozygosity at candidate ovarian tumor suppressor gene loci. Cancer Res 56: 3534-3539, 1996.

33. Silveira CG, Abrão MS, Dias JA Jr, et al: Common chromosomal imbalances and stemness-related protein expression markers in endometriotic lesions from different anatomical sites: the potential role of stem cells. Hum Reprod 27: 3187-3197, 2012.

34. Son JW, Jeong KJ, Jean WS, et al: Genome-wide combination profiling of DNA copy number and methylation for deciphering biomarkers in non-small cell lung cancer patients. Cancer Lett 311: 29-37, 2011.
35. Goumenou AG, Arvanitis DA, Matalliotakis IM, Koumantakis EE and Spandidos DA: Microsatellite DNA assays reveal an allelic imbalance in p16(Ink4), GALT, p53, and APOA2 loci in patients with endometriosis. Fertil Steril 75: 160-165, 2001.

36. Govatati S, Kodati VL, Deenadayal M, Chakravarty B, Shivaji S and Bhanoori M: Mutations in the PTEN tumor gene and risk of endometriosis: a case-control study. Hum Reprod 29: 324-336, 2014.

37. Dun EC, Taylor RN and Wieser F: Advances in the genetics of endometriosis. Genome Med 2: 75, 2010.

38. Kurman RJ and Shih IeM: The origin and pathogenesis of epithelial ovarian cancer: a proposed unifying theory. Am J Surg Pathol 34: 433-443, 2010.

39. Noack F, Schmidt H, Buchweitz O, Malik E and Horny HP: Genomic imbalance and onco-protein expression of ovarian endometrioid adenocarcinoma arisen in an endometriotic cyst. Anticancer Res 24: 151-154, 2004.

40. Pellegrini C, Gori I, Achtari C, et al: The expression of estrogen receptors as well as GREB1, c-MYC, and cyclin D1, estrogenregulated genes implicated in proliferation, is increased in peritoneal endometriosis. Fertil Steril 98: 1200-1208, 2012.

41. Catasús L, Bussaglia E, Rodrguez I, et al: Molecular genetic alterations in endometrioid carcinomas of the ovary: similar frequency of beta-catenin abnormalities but lower rate of microsatellite instability and PTEN alterations than in uterine endometrioid carcinomas. Hum Pathol 35: 1360-1368, 2004.

42. Stewart CJ, Walsh MD, Budgeon CA, Crook ML and Buchanan DB: Immunophenotypic analysis of ovarian endometrioid adenocarcinoma: correlation with KRAS mutation and the presence of endometriosis. Pathology 45: 559-566, 2013.

43. Shaco-Levy R, Sharabi S, Benharroch D, Piura B and Sion-Vardy N: Matrix metalloproteinases 2 and 9, E-cadherin, and beta-catenin expression in endometriosis, low-grade endometrial carcinoma and non-neoplastic eutopic endometrium. Eur J Obstet Gynecol Reprod Biol 139: 226-232, 2008.

44. Hadjihannas MV and Behrens J: CIN By WNT: growth pathways, mitotic control and chromosomal instability in cancer. Cell Cycle 5: 2077-2081, 2006.

45. Bau DT, Hsieh YY, Wan L, et al: Polymorphism of XRCC1 codon arg $399 \mathrm{Gln}$ is associated with higher susceptibility to endometriosis. Chin J Physiol 50: 326-329, 2007.

46. Hsieh YY, Bau DT, Chang CC, Tsai CH, Chen CP and Tsai FJ: XRCC4 codon $247 * \mathrm{~A}$ and XRCC4 promoter $-1394 * \mathrm{~T}$ related genotypes but not XRCC4 intron 3 gene polymorphism are associated with higher susceptibility for endometriosis. Mol Reprod Dev 75: 946-951, 2008

47. Carvalho LF, Abrão MS, Biscotti C, Sharma R, Nutter B and Falcone T: Oxidative cell injury as a predictor of endometriosis progression. Reprod Sci 20: 688-698, 2013.

48. Miao J, Zhang X, Tang QL, Wang XY and Kai L: Prediction value of XRCC 1 gene polymorphism on the survival of ovarian cancer treated by adjuvant chemotherapy. Asian Pac J Cancer Prev 13: 5007-5010, 2012

49. Sáinz de la Cuesta R, Izquierdo M, Cañamero M, Granizo JJ and Manzarbeitia F: Increased prevalence of p53 overexpression from typical endometriosis to atypical endometriosis and ovarian cancer associated with endometriosis. Eur J Obstet Gynecol Reprod Biol 113: 87-93, 2004.

50. Fauvet R, Poncelet C, Hugol D, Lavaur A, Feldmann G and Daraï E: Expression of apoptosis-related proteins in endometriomas and benign and malignant ovarian tumours. Virchows Arch 443: 38-43, 2003.

51. Nezhat F, Cohen C, Rahaman J, Gretz H, Cole P and Kalir T: Comparative immunohistochemical studies of bcl-2 and p53 proteins in benign and malignant ovarian endometriotic cysts. Cancer 94: 2935-2940, 2002.

52. Kim SH, Choi YM, Lee GH, et al: Association between susceptibility to advanced stage endometriosis and the genetic polymorphisms of aryl hydrocarbon receptor repressor and glutathione-S-transferase T1 genes. Hum Reprod 22: 1866-1870, 2007.

53. Cramer DW, Hornstein MD, Ng WG and Barbieri RL: Endometriosis associated with the N314D mutation of galactose1-phosphate uridyl transferase (GALT). Mol Hum Reprod 2: 149-152, 1996.

54. Stefansson H, Einarsdottir A, Geirsson RT, et al: Endometriosis is not associated with or linked to the GALT gene. Fertil Steril 76: 1019-1022, 2001

55. He C, Song Y, He X, Zhang W and Liao L: No association of endometriosis with galactose-1-phosphate uridyl transferase mutations in a Chinese population. Environ Mol Mutagen 47: 307-309, 2006 
56. Babu KA, Reddy NG, Deendayal M, Kennedy S and Shivaji S GSTM1, GSTT1 and CYP1A1 detoxification gene polymorphisms and their relationship with advanced stages of endometriosis in South Indian women. Pharmacogenet Genomics 15: 167-172, 2005.

57. Hsieh YY, Chang CC, Tsai FJ, Lin CC, Chen JM and Tsai CH: Glutathione S-transferase M1*null genotype but not myeloperoxidase promoter $\mathrm{G}-463 \mathrm{~A}$ polymorphism is associated with higher susceptibility to endometriosis. Mol Hum Reprod 10: 713-717, 2004.

58. Arvanitis DA, Goumenou AG, Matalliotakis IM Koumantakis EE and Spandidos DA: Low-penetrance genes are associated with increased susceptibility to endometriosis. Fertil Steril 76: 1202-1206, 2001.

59. Baranova H, Canis M, Ivaschenko T, et al: Possible involvement of arylamine $\mathrm{N}$-acetyltransferase 2, glutathione S-transferases $\mathrm{M} 1$ and T1 genes in the development of endometriosis. Mol Hum Reprod 5: 636-641, 1999.

60. Baranova H, Bothorishvilli R, Canis M, et al: Glutathione S-transferase M1 gene polymorphism and susceptibility to endometriosis in a French population. Mol Hum Reprod 3: 775-780, 1997.

61. Wu CH, Guo CY, Yang JG, et al: Polymorphisms of dioxin receptor complex components and detoxification-related genes jointly confer susceptibility to advanced-stage endometriosis in the taiwanese han population. Am J Reprod Immunol 67: $160-168,2012$

62. Nakago S, Hadfield RM, Zondervan KT, et al: Association between endometriosis and $\mathrm{N}$-acetyl transferase 2 polymorphisms in a UK population. Mol Hum Reprod 7: 1079-1083, 2001

63. Vestergaard AL, Thorup K, Knudsen UB, et al: Oncogenic events associated with endometrial and ovarian cancers are rare in endometriosis. Mol Hum Reprod 17: 758-761, 2011.

64. Nakayama K, Toki T, Zhai YL, et al: Demonstration of focal p53 expression without genetic alterations in endometriotic lesions. Int J Gynecol Pathol 20: 227-231, 2001.

65. Akahane T, Sekizawa A, Purwosunu Y, Nagatsuka M and Okai T: The role of p53 mutation in the carcinomas arising from endometriosis. Int J Gynecol Pathol 26: 345-351, 2007.

66. Stewart CJ, Leung Y, Walsh MD, Walters RJ, Young JP and Buchanan DD: KRAS mutations in ovarian low-grade endometrioid adenocarcinoma: association with concurrent endometriosis. Hum Pathol 43: 1177-1183, 2012.

67. Christie M and Oehler MK: Molecular pathology of epithelial ovarian cancer. J Br Menopause Soc 12: 57-63, 2006.

68. Willner J, Wurz K, Allison KH, et al: Alternate molecular genetic pathways in ovarian carcinomas of common histological types. Hum Pathol 38: 607-613, 2007.

69. Yamamoto S, Tsuda H, Honda K, et al: ACTN4 gene amplification and actinin-4 protein overexpression drive tumour development and histological progression in a high-grade subset of ovarian clear-cell adenocarcinomas. Histopathology 60 1073-1083, 2012.

70.Wu RC, Ayhan A, Maeda D, et al: Frequent somatic mutations of the telomerase reverse transcriptase promoter in ovarian clea cell carcinoma but not in other major types of gynaecological malignancy. J Pathol 232: 473-481, 2014.

71.Prefumo F, Venturini PL and Fulcheri E: Analysis of p53 and c-erbB-2 expression in ovarian endometrioid carcinomas arising in endometriosis. Int J Gynecol Pathol 22: 83-88, 2003.

72. Ying TH, Tseng CJ, Tsai SJ, et al: Association of p53 and CDKN1A genotypes with endometriosis. Anticancer Res 31 4301-4306, 2011.

73. Skirnisdottir I and Seidal T: Association of p21, p21/p27 and p21/ p53 status to histological subtypes and prognosis in low-stage epithelial ovarian cancer. Cancer Genomics Proteomics 10: 27-34, 2013

74. Lee YH, Heo JH, Kim TH, et al: Significance of cell cycle regulatory proteins as malignant and prognostic biomarkers in ovarian epithelial tumors. Int J Gynecol Pathol 30: 205-217, 2011.

75. Yamamoto S, Tsuda H, Miyai K, Takano M, Tamai S and Matsubara O: Accumulative copy number increase of MET drives tumor development and histological progression in a subset of ovarian clear-cell adenocarcinomas. Mod Pathol 25 122-130, 2012.

76. Otsuka J, Okuda T, Sekizawa A, et al: K-ras mutation may promote carcinogenesis of endometriosis leading to ovarian clear cell carcinoma. Med Electron Microsc 37: 188-192, 2004.
77. Govatati S, Deenadayal M, Shivaji S and Bhanoori M Mitochondrial displacement loop alterations are associated with endometriosis. Fertil Steril 99: 1980-1986.e9, 2013.

78. Hsu CC, Lee HC and Wei YH: Mitochondrial DNA alterations and mitochondrial dysfunction in the progression of hepatocellular carcinoma. World J Gastroenterol 19: 8880-8886, 2013.

79. Govatati S, Tipirisetti NR, Perugu S, et al: Mitochondrial genome variations in advanced stage endometriosis: a study in South Indian population. PLoS One 7: e40668, 2012.

80. Cho S, Lee YM, Choi YS, et al: Mitochondria DNA polymorphisms are associated with susceptibility to endometriosis. DNA Cell Biol 31: 317-322, 2012.

81. Kao SH, Huang HC, Hsieh RH, Chen SC, Tsai MC and Tzeng CR Oxidative damage and mitochondrial DNA mutations with endometriosis. Ann NY Acad Sci 1042: 186-194, 2005.

82. Colón-Díaz M, Báez-Vega P, García M, et al: HDAC1 and HDAC2 are differentially expressed in endometriosis. Reprod Sci 19: 483-492, 2012.

83. Cakmak $\mathrm{H}$ and Taylor HS: Implantation failure: molecular mechanisms and clinical treatment. Hum Reprod Update 17: 242-253, 2011

84. Nasu K, Kawano Y, Tsukamoto Y, et al: Aberrant DNA methylation status of endometriosis: epigenetics as the pathogenesis, biomarker and therapeutic target. J Obstet Gynaecol Res 37: 683-695, 2011

85. Kawano Y, Nasu K, Li H, et al: Application of the histone deacetylase inhibitors for the treatment of endometriosis: histone modifications as pathogenesis and novel therapeutic target. Hum Reprod 26: 2486-2498, 2011

86. Wu Y, Strawn E, Basir Z, Halverson G and Guo SW: Aberrant expression of deoxyribonucleic acid methyltransferases DNMT1, DNMT3A, and DNMT3B in women with endometriosis. Fertil Steril 87: 24-32, 2007.

87. Izawa $\mathrm{M}$, Taniguchi $\mathrm{F}$, Terakawa $\mathrm{N}$ and Harada T: Epigenetic aberration of gene expression in endometriosis. Front Biosci (Elite Ed) 5: 900-910, 2013.

88. Khan MA, Sengupta J, Mittal S and Ghosh D: Genome-wide expressions in autologous eutopic and ectopic endometrium of fertile women with endometriosis. Reprod Biol Endocrinol 10: $84,2012$.

89. Kobayashi H, Uekuri C and Shigetomi H: Towards an understanding of the molecular mechanism of endometriosis unbalancing epithelial-stromal genetic conflict. Gynecol Endocrinol 30: 7-15, 2014.

90. Peltomäki P and Bützow R: Pathogenesis of endometriosis and its relationship to gynecological cancers. Epigenomics 3: 689-690, 2011.

91. Tiberi F, Tropea A, Romani F, Apa R, Marana R and Lanzone A Prokineticin 1, homeobox A10, and progesterone receptor messenger ribonucleic acid expression in primary cultures of endometrial stromal cells isolated from endometrium of healthy women and from eutopic endometrium of women with endometriosis. Fertil Steril 94: 2558-2563, 2010.

92. Vinatier D, Cosson M and Dufour P: Is endometriosis an endometrial disease? Eur J Obstet Gynecol Reprod Biol 91: 113-125, 2000.

93. Nyholt DR, Low SK, Anderson CA, et al: Genome-wide association meta-analysis identifies new endometriosis risk loci. Na Genet 44: 1355-1359, 2012

94. Calicchio R, Doridot L, Miralles F, Méhats C and Vaiman D: DNA methylation, an epigenetic mode of gene expression regulation in reproductive science. Curr Pharm Des: Jul 19, 2013 (Epub ahead of print)

95. Kobayashi H, Iwai K, Niiro E, Morioka S and Yamada Y: Fetal programming theory: Implication for the understanding of endometriosis. Hum Immunol 75: 208-217, 2014

96. McCarty CA, Berg RL, Welter JD, Kitchner TE and Kemnitz JW: A novel gene-environment interaction involved in endometriosis. Int J Gynaecol Obstet 116: 61-63, 2012.

97. Missmer SA, Hankinson SE, Spiegelman D, Barbieri RL, Michels KB and Hunter DJ: In utero exposures and the incidence of endometriosis. Fertil Steril 82: 1501-1508, 2004.

98. Parazzini F, Cipriani S, Bravi F, et al: A metaanalysis on alcohol consumption and risk of endometriosis. Am J Obstet Gynecol 209: 106.e1-e10, 2013.

99. Andolf E, Thorsell M and Källén K: Caesarean section and risk for endometriosis: a prospective cohort study of Swedish registries. BJOG 120: 1061-1065, 2013 
100.Kvaskoff M, Bijon A, Clavel-Chapelon F, Mesrine S and Boutron-Ruault MC: Childhood and adolescent exposures and the risk of endometriosis. Epidemiology 24: 261-269, 2013.

101. Missmer SA, Chavarro JE, Malspeis S, et al: A prospective study of dietary fat consumption and endometriosis risk. Hum Reprod 25: 1528-535, 2010.

102. Vitonis AF, Baer HJ, Hankinson SE, Laufer MR and Missmer SA: A prospective study of body size during childhood and early adulthood and the incidence of endometriosis. Hum Reprod 25: 1325-1334, 2010.

103. Guo SW, Simsa P, Kyama CM, et al: Reassessing the evidence for the link between dioxin and endometriosis: from molecular biology to clinical epidemiology. Mol Hum Reprod 15: 609-624, 2009.

104. Marino JL, Holt VL, Chen C and Davis S: Lifetime occupational history and risk of endometriosis. Scand J Work Environ Health 35: 233-240, 2009

105. Nagle CM, Bell TA, Purdie DM, et al: Relative weight at ages 10 and 16 years and risk of endometriosis: a case-control analysis. Hum Reprod 24: 1501-1506, 2009.

106. Kavoussi SK, West BT, Taylor GW and Lebovic DI: Periodontal disease and endometriosis: analysis of the National Health and Nutrition Examination Survey. Fertil Steril 91: 335-342, 2009.

107. Buck Louis GM,Hediger ML and Peña JB: Intrauterine exposures and risk of endometriosis. Hum Reprod 22: 3232-3236, 2007.

108.Kvaskoff M, Mesrine S, Clavel-Chapelon F and Boutron-Ruault MC: Endometriosis risk in relation to naevi, freckles and skin sensitivity to sun exposure: the French E3N cohort. Int J Epidemiol 38: 1143-1, 2009.

109. Kobayashi H, Higashiura Y, Shigetomi $H$ and Kajihara $H$ : Pathogenesis of endometriosis: The role of initial infection and subsequent sterile inflammation (Review). Mol Med Rep 9: 9-15, 2014

110. Prá D, Franke SI, Henriques JA and Fenech M: Iron and genome stability: an update. Mutat Res 733: 92-99, 2012

111. Yamada Y, Shigetomi H, Onogi A, et al: Redox-active ironinduced oxidative stress in the pathogenesis of clear cell carcinoma of the ovary. Int J Gynecol Cancer 21: 1200-1207, 2011

112. Loi M, Del Savio L and Stupka E: Social epigenetics and equality of opportunity. Public Health Ethics 6: 142-153, 2013.

113. Yara S, Lavoie JC, Beaulieu JF, et al: Iron-ascorbate-mediated lipid peroxidation causes epigenetic changes in the antioxidant defense in intestinal epithelial cells: impact on inflammation. PLoS One 8: e63456, 2013.

114. Kim HY, Cho S, Choi YS, et al: Cyclooxygenase-2 (COX-2) gene-765G/C polymorphism and advanced-stage endometriosis in Korean women. Am J Reprod Immunol 68: 238-243, 2012.

115. Barbosa CP, Teles JS, Lerner TG, et al: Genetic association study of polymorphisms FOXP3 and FCRL3 in women with endometriosis. Fertil Steril 97: 1124-1128, 2012

116. Bianco B, Teles JS, Lerner TG, Vilarino FL, Christofolini DM and Barbosa CP: Association of FCRL3 -169T/C polymorphism with endometriosis and identification of a protective haplotype against the development of the disease in Brazilian population. Hum Immunol 72: 774-778, 2011.

117. Teles JS, Bianco B, Vilarino FL, André GM, Christofolini DM and Barbosa CP: Association of FCRL3 C-169T promoter single-nucleotide polymorphism with idiopathic infertility and infertility-related endometriosis. J Reprod Immunol 89 212-215, 2011 .

118. Kitawaki J, Koshiba H, Kitaoka Y, et al: Interferon-gamma gene dinucleotide (CA) repeat and interleukin-4 promoter region $(-590 \mathrm{C} / \mathrm{T})$ polymorphisms in Japanese patients with endometriosis. Hum Reprod 19: 1765-1769, 2004.

119. Kim JJ, Choi YM, Hwang SS, et al: Association of the interferon- $\gamma$ gene (CA)n repeat polymorphism with endometriosis. BJOG 118: 1061-1066, 2011.

120. Rozati R, Vanaja MC and Nasaruddin K: Genetic contribution of the interferon gamma dinucleotide-repeat polymorphism in South Indian women with endometriosis. J Obstet Gynaecol Res 36: 825-831, 2010.

121. Adachi S, Tajima A, Quan J, et al: Meta-analysis of genome-wide association scans for genetic susceptibility to endometriosis in Japanese population. J Hum Genet 55: 816-821, 2010.

122.Gallegos-Arreola MP, Figuera-Villanueva LE, Puebla-Pérez AM, Montoya-Fuentes H, Suarez-Rincon AE and Zúñiga-González GM: Association of TP53 gene codon 72 polymorphism with endometriosis in Mexican women. Genet Mol Res 11: 1401-1408, 2012.
123. D'Amora P, Sato H, Girão MJ, Silva ID and Schor E: Polymorphisms in exons 1B and 1C of the type I interleukin-1 receptor gene in patients with endometriosis. Am J Reprod Immunol 56: 178-184, 2006

124. Hsieh YY, Chang CC, Tsai FJ, Hsu CM, Lin CC and Tsai CH: Interleukin-2 receptor beta (IL-2R beta)-627*C homozygote but not IL-12R beta 1 codon 378 or IL-18 105 polymorphism is associated with higher susceptibility to endometriosis. Fertil Steril 84: 510-512, 2005.

125. Li J, Chen Y, Wei S, et al: Tumor necrosis factor and interleukin-6 gene polymorphisms and endometriosis risk in Asians: a systematic review and meta-analysis. Ann Hum Genet: Dec 6 , 2013 (Epub ahead of print).

126. Kitawaki J, Kiyomizu M, Obayashi H, et al: Synergistic effect of interleukin-6 promoter (IL6 -634C/G) and intercellular adhesion molecule-1 (ICAM-1 469K/E) gene polymorphisms on the risk of endometriosis in Japanese women. Am J Reprod Immunol 56: 267-274, 2006.

127. Fan W, Li S, Chen Q, Huang Z, Ma Q and Xiao Z: Association between interleukin-10 promoter polymorphisms and endometriosis: a meta-analysis. Gene 515: 49-55, 2013.

128. Riiskjaer M, Nielsen K, Steffensen R, Erikstrup C, Forman A and Kruse C: Association of interleukin-10 promoter polymorphism and endometriosis. Am J Reprod Immunol 65: 13-19, 2011.

129. Juo SH, Wu R, Lin CS, Wu MT, Lee JN and Tsai EM: A functional promoter polymorphism in interleukin-10 gene influences susceptibility to endometriosis. Fertil Steril 92: 1228-1233, 2009.

130. Xie J, Wang S, He B, et al: Association of estrogen receptor alpha and interleukin-10 gene polymorphisms with endometriosis in a Chinese population. Fertil Steril 92: 54-60, 2009.

131. Zhang X, Hei P, Deng L and Lin J: Interleukin-10 gene promoter polymorphisms and their protein production in peritoneal fluid in patients with endometriosis. Mol Hum Reprod 13: 135-140, 2007.

132. Hsieh YY, Chang CC, Tsai FJ, Lin CC, Tai CT and Ho M: Association of an A allele for interleukin-10 -627 gene promoter polymorphism with higher susceptibility to endometriosis. J Reprod Med 48: 735-738, 2003.

133. Kitawaki J, Obayashi H, Ohta M, et al: Genetic contribution of the interleukin-10 promoter polymorphism in endometriosis susceptibility. Am J Reprod Immunol 47: 12-18, 2002.

134. Gan XL, Lin YH, Zhang Y, Yu TH and Hu LN: Association of an interleukin-16 gene polymorphism with the risk and pain phenotype of endometriosis. DNA Cell Biol 29: 663-667, 2010.

135. Ayaz L, Celik SK, Çayan F, Aras-Ates N and Tamer L: Functional association of interleukin-18 gene -607 C/A promoter polymorphisms with endometriosis. Fertil Steril 95: 298-300, 2011.

136. Kitawaki J, Xu B, Ishihara H, et al: Association of killer cell immunoglobulin-like receptor genotypes with susceptibility to endometriosis. Am J Reprod Immunol 58: 481-486, 2007.

137. Bianco B, Lerner TG, Trevisan CM, Cavalcanti V, Christofolini DM and Barbosa CP: The nuclear factor- $\kappa \mathrm{B}$ functional promoter polymorphism is associated with endometriosis and infertility. Hum Immunol 73: 1190-1193, 2012.

138. Zhou B, Rao L, Peng Y, et al: A functional promoter polymorphism in NFKB1 increases susceptibility to endometriosis. DNA Cell Biol 29: 235-239, 2010.

139. Kim H, Ku SY, Kim SH, et al: Endothelial nitric oxide synthase gene Glu298Asp polymorphism is associated with advanced stage endometriosis. Hum Reprod 24: 2656-2659, 2009.

140. Lakshmi KV, Shetty P, Vottam K, Govindhan S, Ahmad SN and Hasan Q: Tumor necrosis factor alpha -C850T polymorphism is significantly associated with endometriosis in Asian Indian women. Fertil Steril 94: 453-456, 2010

141. Chae SJ, Kim H, Jee BC, Suh CS, Kim SH and Kim JG: Tumor necrosis factor (TNF)-TNF receptor gene polymorphisms and their serum levels in Korean women with endometriosis. Am J Reprod Immunol 60: 432-439, 2008.

142. Lee GH, Choi YM, Kim SH, et al: Association of tumor necrosis factor-\{alpha\} gene polymorphisms with advanced stage endometriosis. Hum Reprod 23: 977-981, 2008.

143. Asghar T, Yoshida S, Kennedy S, et al: The tumor necrosis factor-alpha promoter $-1031 \mathrm{C}$ polymorphism is associated with decreased risk of endometriosis in a Japanese population. Hum Reprod 19: 2509-2514, 2004

144. Teramoto M, Kitawaki J, Koshiba H, et al: Genetic contribution of tumor necrosis factor (TNF)-alpha gene promoter (-1031, -863 and -857) and TNF receptor 2 gene polymorphisms in endometriosis susceptibility. Am J Reprod Immunol 51: 352-357, 2004. 
145. Christofolini DM, Cavalheiro CM, Teles JS, et al: Promoter $-817 \mathrm{C}>\mathrm{T}$ variant of B lymphocyte stimulator gene (BLyS) and susceptibility to endometriosis-related infertility and idiopathic infertility in Brazilian population. Scand J Immunol 74: 628-631, 2011.

146. Lee HJ, Kim H, Ku SY, Kim SH and Kim JG: Transforming growth factor- $\beta 1$ gene polymorphisms in Korean women with endometriosis. Am J Reprod Immunol 66: 428-434, 2011.

147. Hsieh YY, Chang CC, Tsai FJ, Peng CT, Yeh LS and Lin CC: Polymorphism for transforming growth factor beta 1-509 (TGFB1-509): association with endometriosis. Biochem Genet 43 203-210, 2005.

148.Latha M, Vaidya S, Movva S, et al: Molecular pathogenesis of endometriosis; Toll-like receptor-4 A896G (D299G) polymorphism: a novel explanation. Genet Test Mol Biomarkers 15: 181-184, 2011

149. Tsuchiya M, Tsukino H, Iwasaki M, et al: Interaction between cytochrome P450 gene polymorphisms and serum organochlorine TEQ levels in the risk of endometriosis. Mol Hum Reprod 13: 399-404, 2007

150.Cayan F, Ayaz L, Aban M, Dilek S and Gümüs LT: Role of CYP2C19 polymorphisms in patients with endometriosis Gynecol Endocrinol 25: 530-535, 2009.

151. Szczepańska M, Wirstlein P, Skrzypczak J and Jagodziński PP Polymorphic variants of CYP17 and CYP19A and risk of infertility in endometriosis. Acta Obstet Gynecol Scand 92: 1188-1193, 2013.

152. Bozdag G, Alp A, Saribas Z, Tuncer S, Aksu T and Gurgan T: CYP17 and CYP2C19 gene polymorphisms in patients with endometriosis. Reprod Biomed Online 20: 286-290, 2010.

153. Hsieh YY, Chang CC, Tsai FJ, Lin CC and Tsai CH: Estrogen receptor alpha dinucleotide repeat and cytochrome P450c17alpha gene polymorphisms are associated with susceptibility to endometriosis. Fertil Steril 83: 567-572, 2005.

154. Hsieh YY, Chang CC, Tsai FJ, Lin CC and Tsai CH: Cytochrome $\mathrm{P} 450 \mathrm{c} 17$ alpha 5 -untranslated region $* \mathrm{~T} / \mathrm{C}$ polymorphism in endometriosis. J Genet 83: 189-192, 2004.

155. Wang HS, Wu HM, Cheng BH, et al: Functional analyses of endometriosis-related polymorphisms in the estrogen synthesis and metabolism-related genes. PLoS One 7: e47374, 2012.

156. Trabert B, Schwartz SM, Peters U, et al: Genetic variation in the sex hormone metabolic pathway and endometriosis risk: an evaluation of candidate genes. Fertil Steril 96: 1401-1406.e3, 2011

157. Vietri MT, Cioffi M, Sessa M, et al: CYP17 and CYP19 gene polymorphisms in women affected with endometriosis. Fertil Steril 92: 1532-1535, 2009.

158. Kado N, Kitawaki J, Obayashi H, et al: Association of the CYP17 gene and CYP19 gene polymorphisms with risk of endometriosis in Japanese women. Hum Reprod 17: 897-902, 2002.

159. Ertunc D, Aban M, Tok EC, Tamer L, Arslan M and Dilek S Glutathione-S-transferase P1 gene polymorphism and susceptibility to endometriosis. Hum Reprod 20: 2157-2161, 2005.

160. Tsuchiya M, Katoh T, Motoyama H, Sasaki H, Tsugane S and Ikenoue T: Analysis of the AhR, ARNT, and AhRR gene polymorphisms: genetic contribution to endometriosis susceptibility and severity. Fertil Steril 84: 454-458, 2005.

161. Shaik NA, Govindan S, Kodati V, Rao KP and Hasan Q: Polymorphic $(\mathrm{CAG}) \mathrm{n}$ repeats in the androgen receptor gene: a risk marker for endometriosis and uterine leiomyomas. Hemato Oncol Stem Cell Ther 2: 289-293, 2009.

162. Bilibio JP, Matte U, de Conto E, Genro VK, Souza CA and Cunha-Filho JS: Dopamine receptor D2 genotype (3438) is associated with moderate/severe endometriosis in infertile women in Brazil. Fertil Steril 99: 1340-1345, 2013.

163. Govindan S, Shaik NA, Vedicherla B, Kodati V, Rao KP and Hasan Q: Estrogen receptor-alpha gene (T/C) Pvu II polymorphism in endometriosis and uterine fibroids. Dis Markers 26 149-154, 2009

164. Wang W, Li Y, Maitituoheti M, Yang R, et al: Association of an oestrogen receptor gene polymorphism in Chinese Han women with endometriosis and endometriosis-related infertility. Reprod Biomed Online 26: 93-98, 2013.

165.Lamp M, Peters M, Reinmaa E, et al: Polymorphisms in ESR1, ESR2 and HSD17B1 genes are associated with fertility status in endometriosis. Gynecol Endocrinol 27: 425-433, 2011.

166. Hsieh YY, Wang YK, Chang CC and Lin CS: Estrogen receptor alpha-351 $\mathrm{XbaI} * \mathrm{G}$ and $-397 \mathrm{PvuII} * \mathrm{C}$-related genotypes and alleles are associated with higher susceptibilities of endometriosis and leiomyoma. Mol Hum Reprod 13: 117-122, 2007.
167.Luisi S, Galleri L, Marini F, Ambrosini G, Brandi ML and Petraglia F: Estrogen receptor gene polymorphisms are associated with recurrence of endometriosis. Fertil Steril 85: 764-766, 2006

168. Kim SH, Choi YM, Jun JK, Kim SH, Kim JG and Moon SY Estrogen receptor dinucleotide repeat polymorphism is associated with minimal or mild endometriosis. Fertil Steril 84 774-777, 2005

169. Kitawaki J, Obayashi H, Ishihara H, et al: Oestrogen receptoralpha gene polymorphism is associated with endometriosis, adenomyosis and leiomyomata. Hum Reprod 16: 51-55, 2001

170. Georgiou I, Syrrou M, Bouba I, et al: Association of estrogen receptor gene polymorphisms with endometriosis. Fertil Steril 72: 164-166, 1999.

171. Silva RC, Costa IR, Bordin BM, et al: RsaI polymorphism of the ER $\beta$ gene in women with endometriosis. Genet Mol Res 10: 465-470, 2011.

172.Zulli K, Bianco B, Mafra FA, Teles JS, Christofolini DM and Barbosa CP: Polymorphism of the estrogen receptor $\beta$ gene is related to infertility and infertility-associated endometriosis. Arq Bras Endocrinol Metabol 54: 567-571, 2010.

173. Bianco B, Christofolini DM, Mafra FA, Brandes A, Zulli K and Barbosa CP: $+1730 \mathrm{G} / \mathrm{A}$ polymorphism of the estrogen receptor beta gene (ERbeta) may be an important genetic factor predisposing to endometriosis. Acta Obstet Gynecol Scand 88: 1397-1401, 2009.

174. Wang Z, Yoshida S, Negoro K, Kennedy S, Barlow D and Maruo T: Polymorphisms in the estrogen receptor beta gene but not estrogen receptor alpha gene affect the risk of developing endometriosis in a Japanese population. Fertil Steril 81: 1650-1656, 2004.

175. Tsuchiya M, Nakao H, Katoh T, et al: Association between endometriosis and genetic polymorphisms of the estradiolsynthesizing enzyme genes HSD17B1 and CYP19. Hum Reprod 20: 974-978, 2005.

176. Hu X, Zhou Y, Feng Q, et al: Association of endometriosis risk and genetic polymorphisms involving biosynthesis of sex steroids and their receptors: an updating meta-analysis. Eur J Obstet Gynecol Reprod Biol 164: 1-9, 2012.

177. Wang HS, Cheng BH, Wu HM, et al: A mutant single nucleotide polymorphism of follicle-stimulating hormone receptor is associated with a lower risk of endometriosis. Fertil Steril 95: 455-457, 2011

178. Mafra FA, Bianco B, Christofolini DM, Souza AM, Zulli K and Barbosa CP: Luteinizing hormone beta-subunit gene (LHbeta) polymorphism in infertility and endometriosis-associated infertility. Eur J Obstet Gynecol Reprod Biol 151: 66-69, 2010.

179. Caballero V, Ruiz R, Sainz JA, et al: Preliminary molecular genetic analysis of the receptor interacting protein 140 (RIP140) in women affected by endometriosis. J Exp Clin Assist Reprod 2: $11,2005$.

180. Costa IR, Silva RC, Frare AB, et al: Polymorphism of the progesterone receptor gene associated with endometriosis in patients from Goiás, Brazil. Genet Mol Res 10: 1364-1370, 2011.

181. De Carvalho CV, Nogueira-De-Souza NC, Costa AM, et al: Genetic polymorphisms of cytochrome P450cl7alpha (CYP17) and progesterone receptor genes (PROGINS) in the assessment of endometriosis risk. Gynecol Endocrinol 23: 29-33, 2007.

182. van Kaam KJ, Romano A, Schouten JP, Dunselman GA and Groothuis PG: Progesterone receptor polymorphism +331G/A is associated with a decreased risk of deep infiltrating endometriosis. Hum Reprod 22: 129-135, 2007.

183. Lattuada D, Somigliana E, Viganò P, Candiani M, Pardi G and Di Blasio AM: Genetics of endometriosis: a role for the progesterone receptor gene polymorphism PROGINS? Clin Endocrinol (Oxf) 61: 190-194, 2004.

184. Wieser F, Schneeberger C, Tong D, Tempfer C, Huber JC and Wenzl R: PROGINS receptor gene polymorphism is associated with endometriosis. Fertil Steril 77: 309-312, 2002.

185. Ruiz LA, Dutil J, Ruiz A, et al: Single-nucleotide polymorphisms in the lysyl oxidase-like protein 4 and complement component 3 genes are associated with increased risk for endometriosis and endometriosis-associated infertility. Fertil Steril 96: 512-515, 2011.

186. Trovó de Marqui AB: Genetic polymorphisms and endometriosis: contribution of genes that regulate vascular function and tissue remodeling. Rev Assoc Med Bras 58: 620-632, 2012 (In English, Portuguese). 
187. Shan K, Ying W, Jian-Hui Z, Wei G, Na W and Yan L: The function of the SNP in the MMP1 and MMP3 promoter in susceptibility to endometriosis in China. Mol Hum Reprod 11: 423-427, 2005.

188. Tsai EM, Wang YS, Lin CS, et al: A microRNA-520 mirSNP at the MMP2 gene influences susceptibility to endometriosis in Chinese women. J Hum Genet 58: 202-209, 2013.

189. Cho YJ, Kim NH, Jeong KA, et al: Association between MMP-2 and TIMP-2 gene polymorphisms and advanced-stage endometriosis in Korean women. Am J Reprod Immunol 69: 73-84, 2013

190. Saare M, Lamp M, Kaart T, et al: Polymorphisms in MMP-2 and MMP-9 promoter regions are associated with endometriosis. Fertil Steril 94: 1560-1563, 2010.

191. Shan K, Lian-Fu Z, Hui D, et al: Polymorphisms in the promoter regions of the matrix metalloproteinases-7, -9 and the risk of endometriosis and adenomyosis in China. Mol Hum Reprod 12: 35-39, 2006

192.Han YJ, Kim HN, Yoon JK, et al: Haplotype analysis of the matrix metalloproteinase-9 gene associated with advancedstage endometriosis. Fertil Steril 91: 2324-2330, 2009.

193. Borghese B, Chiche JD, Vernerey D, et al: Genetic polymorphisms of matrix metalloproteinase 12 and 13 genes are implicated in endometriosis progression. Hum Reprod 23 1207-1213, 2008.

194. Gonçalves-Filho RP, Brandes A, Christofolini DM, Lerner TG Bianco B and Barbosa CP: Plasminogen activator inhibitor-1 4G/5G polymorphism in infertile women with and without endometriosis. Acta Obstet Gynecol Scand 90: 473-477, 2011.

195. Bedaiwy MA, Falcone T, Mascha EJ and Casper RF: Genetic polymorphism in the fibrinolytic system and endometriosis. Obstet Gynecol 108: 162-168, 2006.

196. Kang S, Zhao XW, Wang N, Chen SC, Zhou RM and Li Y: Association of polymorphisms of the MMP-2 and TIMP-2 genes with the risk of endometriosis in North Chinese women. Fertil Steril 90: 2023-2029, 2008.

197.Zhang QY, Guan Q, Wang Y, et al: BDNF Val66Met polymorphism is associated with Stage III-IV endometriosis and poor in vitro fertilization outcome. Hum Reprod 27: 1668-1675, 2012.

198. Kim H, Park JH, Ku SY, Kim SH, Choi YM and Kim JG: Association between endometriosis and polymorphisms in insulin-like growth factors (IGFs) and IGF-I receptor genes in Korean women. Eur J Obstet Gynecol Reprod Biol 156: 87-90, 2011.

199. Kim H, Ku SY, Kim SH, Choi YM and Kim JG: Association between endometriosis and polymorphisms in insulin-like growth factor binding protein genes in Korean women. Eur J Obstet Gynecol Reprod Biol 162: 96-101, 2012.

200. Cayan F, Ertunc D, Aras-Ates N, et al: Association of G1057D variant of insulin receptor substrate-2 with endometriosis. Fertil Steril 94: 1622-1626, 2010

201.Kang S, Li SZ, Wang N, et al: Association between genetic polymorphisms in fibroblast growth factor (FGF)1 and FGF2 and risk of endometriosis and adenomyosis in Chinese women. Hum Reprod 25: 1806-1811, 2010.

202. Hsieh YY, Chang CC, Tsai FJ, Lin CC and Tsai CH: T homozygote and allele of epidermal growth factor receptor 2073 gene polymorphism are associated with higher susceptibility to endometriosis and leiomyomas. Fertil Steril 83: 796-799, 2005.

203. Vanaja MC, Rozati R, Nassaruddin K and Vishnupriya S Association of VEGF $+405 \mathrm{G}>\mathrm{C}$ polymorphism with endometriosis. Front Biosci (Elite Ed) 5: 748-754, 2013

204. Xu S, Wu W, Sun H, et al: Association of the vascular endothelial growth factor gene polymorphisms $(-460 \mathrm{C} / \mathrm{T},+405 \mathrm{G} / \mathrm{C}$ and $+936 \mathrm{~T} / \mathrm{C}$ ) with endometriosis: a meta-analysis. Ann Hum Genet 76: 464-471, 2012

205.Emamifar B, Salehi Z, Mehrafza M and Mashayekhi F: The vascular endothelial growth factor (VEGF) polymorphisms and the risk of endometriosis in northern Iran. Gynecol Endocrinol 28: 447-450, 2012

206.Lamp M, Saare M, Laisk T, et al: Genetic variations in vascular endothelial growth factor but not in angiotensin I-converting enzyme genes are associated with endometriosis in Estonian women. Eur J Obstet Gynecol Reprod Biol 153: 85-89, 2010.

207. Attar R, Agachan B, Kuran SB, et al: Genetic variants of vascular endothelial growth factor and risk for the development of endometriosis. In Vivo 24: 297-301, 2010.

208.Liu Q, Li Y, Zhao J, et al: Association of polymorphisms $-1154 \mathrm{G} / \mathrm{A}$ and $-2578 \mathrm{C} / \mathrm{A}$ in the vascular endothelial growth factor gene with decreased risk of endometriosis in Chinese women. Hum Reprod 24: 2660-2666, 2009.
209. Kim SH, Choi YM, Choung SH, Jun JK, Kim JG and Moon SY: Vascular endothelial growth factor gene $+405 \mathrm{C} / \mathrm{G}$ polymorphism is associated with susceptibility to advanced stage endometriosis. Hum Reprod 20: 2904-2908, 2005.

210. Bhanoori M, Arvind Babu K, Pavankumar Reddy NG, et al: The vascular endothelial growth factor (VEGF) $+405 \mathrm{G}>\mathrm{C}$ 5 -untranslated region polymorphism and increased risk of endometriosis in South Indian women: a case control study. Hum Reprod 20: 1844-1849, 2005.

211. Hsieh YY, Chang CC, Tsai FJ, Yeh LS, Lin CC and Peng CT: T allele for VEGF gene-460 polymorphism at the 5'-untranslated region: association with a higher susceptibility to endometriosis. J Reprod Med 49: 468-472, 2004.

212. Kang S, Shi YY,Li Y, et al: Association between genetic variants of the VEGFR-2 gene and the risk of developing endometriosis in Northern Chinese Women. Gynecol Obstet Invest 76: 32-37, 2013.

213. Camargo-Kosugi CM, da Silva ID, Sato H, et al: The V109G polymorphism in the $\mathrm{p} 27$ gene is associated with endometriosis. Eur J Obstet Gynecol Reprod Biol 145: 180-183, 2009.

214. Pagliardini L, Gentilini D, Vigano' P, et al: An Italian association study and meta-analysis with previous GWAS confirm WNT4, CDKN2BAS and FN1 as the first identified susceptibility loci for endometriosis. J Med Genet 50: 43-46, 2013

215. Uno S, Zembutsu H, Hirasawa A, et al: A genome-wide association study identifies genetic variants in the CDKN2BAS locus associated with endometriosis in Japanese. Nat Genet 42: 707-710, 2010.

216. Shi S, Zhou B, Zhang K and Zhang L: Association between two single nucleotide polymorphisms of PDCD6 gene and increased endometriosis risk. Hum Immunol 74: 215-218, 2013.

217. Gomes FM, Bianco B, Teles JS, et al: PTPN22 C1858T polymorphism in women with endometriosis. Am J Reprod Immunol 63: 227-232, 2010 .

218. Ammendola M, Bottini N, Pietropolli A, Saccucci P and Gloria-Bottini F: Association between PTPN22 and endometriosis. Fertil Steril 89: 993-994, 2008.

219. Paskulin DD, Cunha-Filho JS, Souza CA, Bortolini MC, Hainaut P and Ashton-Prolla P: TP53 PIN3 and PEX4 polymorphisms and infertility associated with endometriosis or with post-in vitro fertilization implantation failure. Cell Death Dis 3: e392, 2012

220.Gallegos-Arreola MP Valencia-Rodríguez LE, Puebla-Pérez AM, Figuera LE and Zúñiga-González GM: The TP53 16-bp duplication polymorphism is enriched in endometriosis patients. Gynecol Obstet Invest 73: 118-123, 2012.

221. Jia S, Xu L, Chan Y, et al: p53 codon 72 polymorphism and endometriosis: a meta-analysis. Arch Gynecol Obstet 285: $1657-1661,2012$

222. Ribeiro Júnior CL, Arruda JT, Silva CT and Moura KK: Analysis of p53 codon 72 gene polymorphism in Brazilian patients with endometriosis. Genet Mol Res 8: 494-499, 2009.

223. Hsieh YY and Lin CS: P53 codon 11, 72, and 248 gene polymorphisms in endometriosis. Int J Biol Sci 2: 188-193, 2006.

224. Chang CC, Hsieh YY, Tsai FJ, Tsai CH, Tsai HD and Lin CC: The proline form of $\mathrm{p} 53$ codon 72 polymorphism is associated with endometriosis. Fertil Steril 77: 43-45, 2002.

225. Bhanoori M, Deenadayal M, Kennedy S and Shivaji S: The G2964A 3'-untranslated region polymorphism of the signal transducer and activator of transcription 6 gene is associated with endometriosis in South Indian women. Hum Reprod 22: 1026-1030, 2007.

226. Yoshida K, Yoshihara K, Adachi S, et al: Possible involvement of the E-cadherin gene in genetic susceptibility to endometriosis. Hum Reprod 27: 1685-1689, 2012

227. Govatati S, Tangudu NK, Deenadayal M, Chakravarty B, Shivaji S and Bhanoori M: Association of E-cadherin single nucleotide polymorphisms with the increased risk of endometriosis in Indian women. Mol Hum Reprod 18: 280-287, 2012.

228. Shan K, Xiao-Wei M, Na W, et al: Association of three single nucleotide polymorphisms of the E-cadherin gene with endometriosis in a Chinese population. Reproduction 134: 373-378, 2007.

229. Aghajanpour L, Mashayekhi F and Rajaei F: Intercellular adhesion molecule-1 (ICAM-1) gene polymorphism and endometriosis in northern Iran. Arch Gynecol Obstet 283: 1035-1039, 2011

230. Chang CY, Chen Y, Lin WC, et al: MUC2 polymorphisms are associated with endometriosis development and infertility: a case-control study. BMC Med Genet 13: 15, 2012. 
231. Chang CY, Chang HW, Chen CM, et al: MUC4 gene polymorphisms associate with endometriosis development and endometriosis-related infertility. BMC Med 9: 19, 2011.

232. Falconer $\mathrm{H}$, Sundqvist J, Xu H, et al: Analysis of common variations in tumor-suppressor genes on chr1p36 among Caucasian women with endometriosis. Gynecol Oncol 127: 398-402, 2012.

233. Wu HH, Wang NM, Lin CY and Tsai HD: Genetic alterations of HOXA10 and their effect on the severity of endometriosis in a Taiwanese population. Reprod Biomed Online 16: 416-424, 2008.

234. Hwang KR, Choi YM, Kim JM, et al: Association of peroxisome proliferator-activated receptor-gamma 2 Pro12Ala polymorphism with advanced-stage endometriosis. Am J Reprod Immunol 64: 333-338, 2010.

235.Kiyomizu M, Kitawaki J, Obayashi H, et al: Association of two polymorphisms in the peroxisome proliferator-activated receptor-gamma gene with adenomyosis, endometriosis, and leiomyomata in Japanese women. J Soc Gynecol Investig 13: 372-377, 2006.

236. Ishii K, Takakuwa K, Kashima K, Tamura M and Tanaka K Associations between patients with endometriosis and HLA class II; the analysis of HLA-DQB1 and HLA-DPB1 genotypes. Hum Reprod 18: 985-989, 2003.

237. Ishii K, Takakuwa K, Mitsui T and Tanaka K: Studies on the human leukocyte antigen-DR in patients with endometriosis: genotyping of HLA-DRB1 alleles. Hum Reprod 17: 560-563, 2002.

238. Grechukhina O, Petracco R, Popkhadze S, et al: A polymorphism in a let-7 microRNA binding site of KRAS in women with endometriosis. EMBO Mol Med 4: 206-217, 2012.
239. Hsieh YY, Lee CC, Chang CC, Wang YK, Yeh LS and Lin CS: Angiotensin I-converting enzyme insertion-related genotypes and allele are associated with higher susceptibility of endometriosis and leiomyoma. Mol Reprod Dev 74: 808-814, 2007.

240. Hsieh YY, Chang CC, Tsai FJ, Hsu CM, Lin CC and Tsai $\mathrm{CH}$ : Angiotensin I-converting enzyme ACE $2350 * \mathrm{G}$ and ACE-240*T-related genotypes and alleles are associated with higher susceptibility to endometriosis. Mol Hum Reprod 11: $11-14,2005$

241. Kim JG, Kim H, Ku SY, et al: Association between human alpha 2-Heremans Schmidt glycoprotein (AHSG) polymorphism and endometriosis in Korean women. Fertil Steril 82: 1497-1500, 2004.

242. Borghese B, Santulli P, Héquet D, et al: Genetic polymorphisms of DNMT3L involved in hypermethylation of chromosomal ends are associated with greater risk of developing ovarian endometriosis. Am J Pathol 180: 1781-1786, 2012.

243. Szczepańska M, Mostowska A, Wirstlein P, et al: Polymorphic variants of folate and choline metabolism genes and the risk of endometriosis-associated infertility. Eur J Obstet Gynecol Reprod Biol 157: 67-72, 2011.

244.Zhao ZZ, Croft L, Nyholt DR, et al: Evaluation of polymorphisms in predicted target sites for micro RNAs differentially expressed in endometriosis. Mol Hum Reprod 17: 92-103, 2011.

245. Chun S, Kim H, Ku SY, Suh CS, Kim SH and Kim JG: The association between endometriosis and polymorphisms in the interleukin-1 family genes in Korean women. Am J Reprod Immunol 68: 154-163, 2012

246. Viganò P, Infantino M, Lattuada D, et al: Intercellular adhesion molecule-1 (ICAM-1) gene polymorphisms in endometriosis. Mol Hum Reprod 9: 47-52, 2003. 